\title{
WIATRAKI NA ŻUŁAWACH W PIERWSZEJ POŁOWIE XV W.
}

Badania nad warunkami życia ludności wiejskiej i organizacją gospodarki rolnej w średniowieczu mają już długą tradycję. Niestety, $\mathrm{w}$ ostatnich dziesięcioleciach $\mathrm{w}$ polskiej nauce historycznej widoczny jest $\mathrm{w}$ tym zakresie wyraźny regres. W ramach prowadzonych dawniej prac starano się odtworzyć warunki egzystencji ludności wiejskiej w państwie Zakonu Krzyżackiego w Prusach ${ }^{1}$. Wśród zagadnień szczegółowych rozpatrywano m.in. problem organizacji gospodarki młyńskiej na ziemiach polskich i w państwie krzyżackim². Powstały także opracowania dotyczące tej problematyki na specyficznym terenie, jakim były - zarówno w okresie krzyżackim, jak i w Rzeczypospolitej - Żuławy ${ }^{3}$. W tym artykule przyjrzymy się roli wiatraków w ekonomice krzyżackiej tych terenów w pierwszej połowie XV w. ${ }^{4}$

${ }^{1}$ B. Geremek, Problem sity roboczej $w$ Prusach $w$ pierwszej połowie XV w., PH, t. 48, 1957, z. 2, s. 195-233; tenże, Ze studiów nad stosunkami gospodarczymi między miastem a wsiq $w$ Prusach Krzyżackich $w$ I pot. XV w., PH, t. 47, 1956, z. 1, s. $48-102$.

${ }^{2}$ M. Dembińska, Przetwórstwo zbożowe w Polsce średniowiecznej (X-XIV wiek), Warszawa 1973; B. Baranowski, Polskie mtynarstwo, Wrocław 1977; H. Steffen, Die ländliche Mühlwesen im Deutsche Ordenslande, „Zeitschrift des Westpreußischen Geschichtsvereins" (dalej: ZWG) 58, 1918, s. 73-92.

${ }^{3}$ W. Długokęcki, Z dziejów mtynarstwa w komturstwie malborskim $w$ XIII-XV wieku, „Rocznik Elblaski” 12, 1991, s. 21-62; tenże, Mtynarstwo w komturstwie malborskim $w$ XIII-XV w., w: W. Długokęcki, J. Kuczyński, B. Pospieszna, Młyny w Malborku $i$ okolicy od XIII do XIX wieku, Malbork 2004, s. 7-36. Druga praca zawiera ważne uzupełnienia, dotyczące sieci wiatraków.

${ }^{4}$ Ogólne uwagi na temat roli wiatraków w młynarstwie państwa Zakonu Krzyżackiego w Prusach zob. R. Kubicki, Mtynarstwo w państwie zakonu krzyżackiego w Prusach $w$ XIII-XV wieku (do 1454 r.), Gdańsk 2012, s. 190-191, 324, 327-328. 
W ramach państwa Zakonu Krzyżackiego w XV w. Żuławy podlegały kilku jednostkom administracyjnym ${ }^{5}$. Północna część Żuław Gdańskich (zwanych w średniowieczu Żuławami Steblewskimi lub Małymi) wchodziła w skład urzędu leśnego komturstwa gdańskiego, pas między Wisłą i Motławą tworzył wójtostwo z siedzibą w Grabinach Zameczku i należał do komturstwa malborskiego, a południowa część podlegała wójtowi tczewskiemu. Z kolei Żuławy Wielkie należały do komturstwa malborskiego, a Żuławy Fiszewskie częściowo do komturstwa elbląskiego i dzierzgońskiego ${ }^{6}$. Odrębność zasad gospodarowania na tych terenach wynikała przede wszystkim z lokalnych warunków wodnych i potrzeby stałego odwadniania terenów wykorzystywanych rolniczo. Jednym z elementów specyfiki tego terenu była także organizacja młynarstwa, która ze względu na warunki geograficzne nie mogła opierać się, tak jak działo się na innych terenach, wyłącznie na sieci młynów wodnych. $\mathrm{W}$ ich zastępstwie budowano tu wiatraki, które od średniowiecza aż po połowę XX w. były charakterystycznym elementem krajobrazu?

\footnotetext{
${ }^{5} \mathrm{Na}$ temat osadnictwa na tych terenach zob. B. Schmid, Die Bau- und Kunstdenkmäler der Provinz Westpreußen, t. 4: Marienburg (Die Städte Neuteich und Tiegenhof und die ländlichen Ortschaften), Danzig 1919, s. I-XVI; K. Kasiske, Die Siedlungstätigkeit des Deutschen Ordens im östlichen Preußen bis zum Jahre 1410, Königsberg 1934, s. 41-45; W. Długokęcki, Osadnictwo na Żuławach w XIII i poczatkach XIV w., Malbork 1992; tenże, Osadnictwo pótnocnej części Żuław Wielkich w XIV - I pot. $X V w$., w: Żuławy i Mierzeja - moje miejsce na ziemi. Materiaty z sesji naukowej odbytej $w$ dniach 6-7 X 2000 r. w Stegnie zorganizowanej przez Starostwo Powiatowe w Nowym Dworze Gdańskim, Stowarzyszenie Miłośników Nowego Dworu Gdańskiego, Klub Nowodworski, red. D.A. Dekański, Gdańsk 2001, s. 115-127; tenże, Osadnictwo na Żuławach Gdańskich w średniowieczu (do 1454 roku), „Zapiski Historyczne” 68, 2003, z. 2-3, s. 45-62.

${ }^{6} \mathrm{Na}$ temat podziałów terytorialnych Żuław i ich granic zob. W. Długokęcki, Osadnictwo na Żuławach $w$ XIII i poczatkach XIV w..., s. 29-30, 81-83, 127-128. W prezentowanym tu artykule uwzględniono dodatkowo wiatraki funkcjonujace na prawym brzegu Wisły Gdańskiej, choć teren ten już w średniowieczu zaliczano do Mierzei, później Mierzei Gdańskiej.

${ }^{7}$ Podstawowe informacje na temat funkcjonowania wiatraków w Europie, ich rodzajów i rozprzestrzeniania zestawił J.C. Notebaart, Windmühlen der Stand der Forschung über das Vorkommen und den Ursprung, Den Haag-Paris 1972, s. 13-34 (typy wiatraków), 62-78 (wiatraki w Niemczech), 124-149 (wiatraki w Niderlandach), 155-163 (wiatraki na terenie Polski). Ciekawe dane zawiera też praca na temat obrazu młynarstwa w kulturze minionych stuleci: J. Mager, G. Meißner, W. Orf, Die Kulturgeschichte der Mühlen, Leipzig 1988. Na temat wiatraków na Żuławach zob. B. Schmid, dz. cyt., s. LXXXVI-LXXXVIII; tenże, Erhaltung von Windmühlen, w: Die Denkmalpflege in der Provinz Westpreußen in den Jahren 1920 bis 1931, 17. Bericht, Königsberg 1932, s. 25-28.
} 


\section{Regulacje Zakonu Krzyżackiego w zakresie budowy wiatraków}

Pierwsze wzmianki o organizacji młynarstwa na terenie Żuław pojawiaja się wraz $\mathrm{z}$ intensyfikacja osadnictwa, prowadzona na tym terenie przez Krzyżaków w XIV w. Ważną okolicznościa mającą wpływ na polityke gospodarczą Zakonu było uznanie prawa do budowy młynów wodnych do wyłącznych uprawnień władzy zwierzchniej, a więc zarówno Zakonu, jak i biskupów oraz kapituł na kontrolowanych przez nie terenach. Regale młyńskie, początkowo dotyczące młynów wodnych, rozciagnięto również na prawo do budowy wiatraków. Oznaczało to w praktyce, że wznoszenie nowych urządzeń wymagało zgody władcy terytorialnego ${ }^{8}$. Dzięki takiemu statusowi prawnemu młynów wodnych i wiatraków Krzyżacy, organizując strukturę wsi, mogli stosować system rezerwacji miejsc na młyny. W ten sam sposób gwarantowali sobie również prawo do budowy karczem ${ }^{9}$. Rezerwacja polegała na umieszczaniu odpowiednich klauzul w przywilejach lokacyjnych wydawanych przy okazji zakładania nowych osad ${ }^{10}$. Gwarantowały one, że wyłaczne prawo do ewentualnej budowy młyna w obrębie danej wsi mieć będzie Zakon. Oczywiście tego typu działania nie dotyczyły tylko Żuław, co więcej, stosowali je w swych dobrach na mniejszą skalę również biskupi i kapituły. Dla terenu Żuław tego typu rezerwacje znalazły się w przywilejach dla wsi: Mirowo (1318 r. $)^{11}$, Nowa Kościelnica $(1320 \text { r. })^{12}$,

${ }^{8} \mathrm{Na}$ temat problemu powstania regale młyńskiego w państwie krzyżackim dyskutowali: G. Kisch, Die Mühlenregal im Deutsch-Ordensgebiete, „Zeitschrift der Savigny -stiftung für Rechtsgeschichte, Germanische Abtheilung” 48, 1928, s. 176-193; inaczej A. Semrau, Zur Geschichte des Mühlenregals im Deutschordenslande, „Mitteilungen des Coppernicus-Vereins für Wissenschaft und Kunst zu Thorn” 37, 1929, s. 1-10. Podsumowanie dyskusji: G. Kisch, Das Mühlenrecht im Deutschordensgebiete, w: Studien zur Rechts- und Sozialgeschichte des Deutschordenslandes, Sigmaringen 1973, s. 87-164.

${ }^{9}$ H. Steffen, Das ländliche Krugwesen im Deutschordensstaate. Ein Beitrag zur Kulturgeschichte Altpreußens, ZWG, t. 56, 1916, s. 219-245.

${ }^{10}$ Rezerwacje dla komturstwa malborskiego omówił W. Długokęcki, $Z$ dziejów mtynarstwa..., s. 26. Zestawienie rezerwacji miejsc na młyny dokonywanych przez różne instytucje na terenie całego państwa krzyżackiego zob. R. Kubicki, dz. cyt., s. 88-93.

${ }^{11}$ „Uff desem vorbenanten gute neme wir us und behalden unsern brudern kreczem, moelen, moelstete, molwege und garten, die dorczu togen, ewiclichen czu nucze"; PrU, t. 2, wyd. M. Hein, E. Maschke, Königsberg 1939, nr 214, s. 144.

12 „Excepimus denique in bonis prenominatis tabernas et molendina et loca ipsis apta, que nostre domus usui specialiter applicamus"; Codex Diplomaticus Warmiensis (dalej: CDW), wyd. C.P. Woelky, J.M. Saage, t. 1, Mainz 1860, nr 204, s. 353; regest dokumentu w PrU, t. 2, nr 299, s. 194. 
Marynowy (1321 r. $)^{13}$, Stara Kościelnica (1323 r. $)^{14}$ i Żelichowo (1328 r. $)^{15}$. W późniejszym czasie zostały zaś zrealizowane w przypadku wsi Marynowy, Stara Kościelnica, Nowa Kościelnica i Żelichowo.

Dokumenty lokacyjne dla wspomnianych wsi zawierały formułę brzmiąca zazwyczaj następujacco: „we wspomnianych dobrach wyłaczamy karczmy i młyny i miejsca na nie, drogi, miejsca i budynki przynależne, które naszemu domowi w szczególności rezerwujemy". Dokumenty te wystawiane były przez: wielkiego szpitalnika i komtura elblaskiego Hermana (Nowa Kościelnica, Żelichowo), komtura elblaskiego, później wielkiego komtura i namiestnika wielkiego mistrza, Fryderyka z Wildenbergu (Mirowo) oraz wielkiego komtura Wernera z Orseln (Marynowy, Stare Kościelnica). Zwraca uwagę fakt, że formuły o rezerwacji miejsca na karczmę i młyn dla Zakonu umieszczali w swych przywilejach kolejni komturowie elblascy. Dotyczyły one nie tylko miejscowości, które weszły w skład komturstwa malborskiego, ale również tych położonych $\mathrm{w}$ komturstwie elbląskim. Tam rezerwacje, których później nie wykorzystano, umieścili w swych przywilejach komturowie elblasscy: Henryk z Gery (Pogrodzie 1305 r., Podgórze 1308 r.) ${ }^{16}$, Fryderyk von Wildenberg (Zalesie 1314 r., Kamionek Wielki 1315 r.), Herman (Milejewo 1320 r., Krasinek 1323 r., Brzezina 1324 r., Sapy 1328 r., Stegny 1328 r., Majewo 1331 r. $)^{17}$. Zrealizowano natomiast rezerwacje komturów elblaskich dotyczące wsi Łęguty ${ }^{18}$ 1301 r. (komtur Konrad von Lichtenhain), Rychliki ${ }^{19}$ - 1310 r. (komtur Henryk z Gery), Aniołowo ${ }^{20}-1315$ r. (komtur Fryderyk z Wildenbergu), Kamiennik Wielki ${ }^{11}-1320$ r. (komtur Henryk z Iseberg),

${ }^{13}$ „Ander creczschme ane desen und molen und molestete, molwege und garthen, die dorczu togen, neme wir us und behalden unsern brudern ewiclichin czu nuczen"; PrU, t. 2, nr 360, s. 268.

${ }^{14}$ „Obir das behalde wir unser moelstete und garthen und kreczmestete, die doczu togen, unsern brudern ewiclichen czu nuczcze"; tamże, nr 407, s. 296.

${ }_{15}$ Tamże, nr 616, s. 407.

${ }^{16}$ CDW, t. 1, nr 132, s. 232; PrU, t. 1/2, wyd. R. Philippi, C.P. Woelky, Königsberg 1882 , nr 897, s. 564.

${ }^{17}$ CDW, t. 1 , nr 206, s. 354; PrU, t. 2, nr 440, s. 314; nr 480, s. 329; nr 602, s. 396; nr 613, s. 405; nr 711, s. 473.

${ }^{18} \mathrm{PrU}$, t. 1/2, nr 761, s. 473.1402 r. - wzmianka o młynie; Archiwum Państwowe w Gdańsku (dalej: APG), Akta miasta Elblaga, Altt Zinsbuch des Hauses Elbing, sygn. $369,1 / 2102$, k. $62 \mathrm{v}$.

${ }^{19}$ CDW, t. 1, nr 152, s. 263.1383 r. - wzmianka o młynie; Das Pfennigsschuldbuch der Komturei Christburg, wyd. H. Wunder, Köln-Berlin 1969 (dalej: PKCh), s. 190, 201.

${ }^{20} \mathrm{PrU}$, t. 2, nr 141, s. 94.1402 r.-wzmianka o młynie; APG, sygn. 369,1/2102, k. 33v.

${ }^{21} \mathrm{PrU}$, t. 2, nr 294, s. 190.1402 r. - wzmianka o młynie; APG, sygn. 369,1/2102, k. 48 r. 
Zastawno $22-1326$ r. (komtur Herman), Marianka ${ }^{23}$ - 1334 r. i Zajaczkowo ${ }^{24}-1335$ r. (komtur Zygfryd von Sitten). Poza komturami elblaskimi tak licznie formułę rezerwująca prawo budowy i posiadania młynów w nowo zakładanych wsiach stosowali w latach siedemdziesiątych XIV w. komturowie gdańscy Konrad Zollner von Rotenstein (w przywilejach dla wsi Kębłowo i Ciechocino), a przede wszystkim Zygfryd Walpot von Bassenheim (Strzelno, Obliwice, Glewitz, Wilkowo, Wielka Wieś, Prusewo, Bartlin) ${ }^{25}$. Przytoczone przykłady moga wskazywać, że umieszczanie w dokumentach formuły mówiącej o rezerwacji nie zawsze musiało być przejawem rzeczywistych planów Zakonu, a wynikało po prostu z posługiwania się przez kolejnych urzędników, przede wszystkim komturów elblaskich, stałymi formularzami przywilejów lokacyjnych dla wsi. Skłania to do ostrożnego podchodzenia do kwestii każdej z rezerwacji, która należy widzieć w kontekście prowadzonej w tym czasie akcji osadniczej. W przypadku Żuław pierwotne rezerwacje miejsca na młyn wodny we wsiach Mirowo (1318 r.) i Żelichowo (1328 r.) nie zostały zrealizowane, a w ich miejsce powstały dwa wiatraki w okolicy Mirowa, położone w Tuji i Nowym Stawie oraz dwa wiatraki w Żelichowie, zamiast planowanego tam młyna wodnego ${ }^{26}$. Wynika z tego, że w kilku przypadkach Zakon z czasem zrezygnował z pierwotnych zamierzeń co do budowy młynów wodnych, ze względu na trudne warunki hydrograficzne, zastępując je wiatrakami.

\section{Sieć wiatraków w pierwszej polowie XV w.}

Niestety, stan zachowania źródeł nie pozwala na odtworzenie chronologii budowy sieci młynów wodnych i wiatraków na Żuławach. Zapewne powstały one wkrótce po zorganizowaniu wsi, a ich liczba rosła

${ }^{22} \operatorname{PrU}$, t. 2, nr 557, s. 373. 1446 r. - wzmianka o młynie; Visitationen im Deutschen Orden im Mittelalter, wyd. M. Biskup, I. Janosz-Biskupowa, Marburg 2002 (Quellen und Studien zur Geschichte des Deutschen Ordens, 50), (dalej: Visitationen), cz. 1: 1236-1449, nr 120, s. 238.

${ }^{23} \mathrm{PrU}$, t. 2, nr 830, s. 558. 1407 r. - wzmianka o młynie; APG, sygn. 369,1/2102, k. 31 .

${ }^{24}$ CDW, t. 1 (Regesta), nr 270, s. 158 (nr 422). 1393 r. - wzmianka o młynie; APG, sygn. $369,1 / 2102, \mathrm{k} .49 \mathrm{v}$.

${ }^{25}$ Wszystkie dokumenty opublikowano, zob. Księga komturstwa gdańskiego, wyd. K. Ciesielska, I. Janosz-Biskupowa, Warszawa-Poznań 1985 (Fontes, 70), (dalej: $\mathrm{KKG}$ ), wg indeksu.

${ }^{26}$ Zagadnienie to prezentuje załączona mapa wiatraków na Żuławach w pierwszej połowie XV w. 
proporcjonalnie do rozwoju produkcji zbożowej ${ }^{27}$. Dopiero źródła skarbowe Zakonu z końca XIV w., a pełniej te z początków XV w., notuja istniejące wówczas urządzenia przemiałowe. Funkcjonowało wówczas na tym terenie ponad trzydzieści wiatraków i trochę mniejsza liczba młynów wodnych ${ }^{28}$. Oczywiście te ostatnie były zazwyczaj urządzeniami większymi, tak jak np. kompleks zbudowany na Młynówce Malborskiej, obejmujacy Młyn Nowy, Młyn Słodowy, Młyn Szewski, Młyn Średni, Młyn Piekarski i Landmel ${ }^{29}$. Najstarsza wzmianka o wiatraku działajacym na Żuławach pochodzi dopiero z 1391 r. i dotyczy młynarza z wiatraka w Leklowach ${ }^{30}$. Wiatrak ten istniał zapewne znacznie wcześniej, a później miał tam powstać także młyn wodny ${ }^{31}$. W 1396 r. odnotowano fakt budowy przez Zakon wiatraka we wsi Lipinka ${ }^{32}$. Z kolei w $1400 \mathrm{r}$. w wykazach czynszowych wzmiankowano dwa wiatraki w Żelichowie ${ }^{33}$, a w 1402 r. wiatrak w Fiszewie ${ }^{34}$. Z 1404 r. pochodzi zaś informacja o istnieniu wiatraka przed dworem zakonnym w Mątowach i wiatraka $\mathrm{w}$ Tuji ${ }^{35}$. O innych pierwsze informacje pochodzą dopiero z lat trzydziestych (Leśnowo) i czterdziestych XV w. (Lasowice Wielkie, Stara Wisła). Nie należy jednak wątpić, że istniały one znacznie wcześniej.

${ }^{27}$ Zob. załączony wykaz wiatraków wzmiankowanych na Żuławach w pierwszej połowie XV w. (zob. tab. 4).

${ }^{28}$ Dla terenu komturstwa malborskiego ogólną liczbę 48-50 młynów, w tym: 13 młynów wodnych (ewentualnie 15), 27 wiatraków, 6 młynów zwierzęcych i młyn pływający, podał W. Długokęcki, Mtynarstwo..., s. 30. Wskazał również, że liczby te sa zaniżone, szczególnie w przypadku wiatraków. Przyjmując, że każdy z nich pracował średnio dla 2 wsi, na Wielkich Żuławach byłoby ich 23 . W moim zestawieniu odnotowałem wzmianki wskazujace na istnienie co najmniej 33 wiatraków, zob. tab. 4.

${ }^{29}$ Omówienie tego założenia zob. B. Schmid, Der Mühlengraben, w: Die Bau und Kunstdenkmäler Pomesaniens, 3. Kreis Stuhm, Danzig 1909, s. 293-300; W. Długokęcki, $Z$ dziejów mtynarstwa..., s. 31-41.

${ }^{30}$ Wzmianki zestawił A. Semrau, Die Siedlungen im Kammeramt Fischau (Komturei Christburg) im Mittelalter, „Mitteilungen des Coppernicus-Vereins für Wissenschaft und Kunst zu Thorn" 44, 1936, s. 91.

${ }^{31}$ Zob. W. Długokęcki, $Z$ dziejów mtynarstwa..., s. 28-29, który przyjmuje, że najpóźniej w $1407 \mathrm{r}$. znajdowały się we wsi 2 młyny. W okolicy istniał ponadto młyn łodziowy, pływający po Starym Nogacie koło wsi Krasnołęka, wzmiankowany w latach 1400-1412; Das Zinsbuch des Hauses Marienburg, wyd. W. Ziesemer, Marienburg 1910 (dalej: ZHM), s. 40; Das Marienburger Konventsbuch der Jahre 1399-1412, wyd. W. Ziesemer, Danzig 1913 (dalej: MK), s. 226, 274.

${ }^{32}$ A. Sielmann, Die Reste des Marienburger Konventsbuches aus den Jahren 1395-1398, ZWG, t. 60, 1920, s. 70.

${ }^{33}$ ZHM, s. 31; MK, s. 19.

${ }^{34}$ APG, sygn. 369,1/2102, k. 26v.

${ }^{35}$ Handelsrechnungen des Deutschen Ordens, wyd. C. Sattler, Leipzig 1887 (dalej: HRD), s. 46. 
Problem z odtworzeniem sieci wiatraków wynika oczywiście z ich nietrwałości jako obiektów drewnianych. Nie pozostały często żadne ślady po ich zabudowie, inaczej niż przypadku młynów wodnych, na których istnienie wskazują zachowane założenia wodne - choćby stawy młyńskie i sztucznie regulowane młynówki. Wpływ na położenie wiatraków na Żuławach miała też inna okoliczność. Jak zauważył Wolfgang La Baume, warunki naturalne powodowały, że osadnictwo w dolinie Wisły musiało skupiać się tylko na wybranych terenach, zdatnych do zasiedlenia ${ }^{36}$. Po dokonaniu melioracji całego obszaru stały się one naturalnymi wzniesieniami, na których mogły powstawać wiatraki ${ }^{37}$. Prowadzone $\mathrm{w}$ ich obrębie badania archeologiczne potwierdziły ślady dawnego osadnictwa. Takie wzniesienia, na których mogły powstać wiatraki, znajdowały się m.in. koło Tragamina, Kraszewa, Gnojewa, Lubieszewa, Lasowic Wielkich, Lipinki, Myszewka, Janówka i Ostaszewa ${ }^{38}$. Istnienie wiatraków w tych lokalizacjach, wyjąwszy Ostaszewo i Myszewko, potwierdzaja już źródła pochodzące z początku XV w. Budując zaś nowe wiatraki, stawiane w miejsce już wyeksploatowanych, wybierano zazwyczaj dotychczasowa lokalizację, podobnie jak w przypadku młynów wodnych. Przy rozważaniu budowy wiatraków drugim ważnym czynnikiem, obok warunków terenowych uniemożliwiajacych wzniesienie młyna wodnego, była kwestia spodziewanych kosztów budowy i użytkowania. Budowa młyna wodnego i opłacalność jego późniejszej eksploatacji mogła okazywać się mniejsza niż wiatraka, szczególnie gdy poziom lokalnej produkcji zbożowej nie wymagał zastosowania urządzeń o dużych możliwościach przemiałowych. Dla przykładu, w 1396 r. konwent malborski wydatkował 19 grzywien na budowę wiatraka w Lipince i 36 grzywien na zakup pary kamieni młyńskich, co byłoby sumą bardzo dużą (być może był to błędny zapis w rachunkach) ${ }^{39}$. Podobnie w 1412 r. prokuratorowi w Mątowach wypłacono z kasy konwentu malborskiego 24 grzywny na budowę młyna w Starej Kościelnicy i zakup kamieni

${ }^{36}$ W. La Baume, Die Besiedlung des Weichsel-Nogat-Deltas in vor- und frühgeschichtlicher Zeit, w: Das Weichsel-Nogat-Delta, Danzig 1924 (Quellen und Darstellungen zur Geschichte Westpreußens, 11), s. 66; R. Kubicki, dz. cyt., s. 129-130.

${ }^{37}$ Oczywiście czasem do tego celu sypano też, dużym nakładem kosztów, sztuczne wzniesienia.

${ }^{38}$ W. La Baume, dz. cyt., s. 67, 71, 82, 85, 91, 102.

${ }^{39}$ A. Sielmann, dz. cyt., s. 70. System monetarny w Prusach przedstawiał się następująco: 1 grzywna pruska $=4$ wiardunki $=24$ skojce $=45$ półskojcy $=60$ szelagó $=180$ kwartników = 720 denarów; zob. W. Odyniec, Chetmiński system miar i chetmińska stopa mennica $w$ rozwoju historycznym, w: Ksiega pamiatkowa 750-lecia prawa chetmińskiego, red. Z. Zdrójkowski, t. 1, Toruń 1990, s. 406. 
młyńskich ${ }^{40}$. Niewielki koszt jego budowy wskazuje, że był to najpewniej wiatrak. Dla porównania ogólne koszty budowy młyna wodnego w Działdowie w 1407 r., według rachunku komtura ostródzkiego, wyniosły aż 750 grzywien $^{41}$, a wiatraka miejskiego, który wzniesiono w Chełmnie w 1443 r., ogółem 222,5 grzywny ${ }^{42}$. W tym kontekście ważna jest również informacja o zakupie w $1406 \mathrm{r}$. wiatraka w Leklowach przez młynarza Mikołaja. Miał on za niego zapłacić komturowi dzierzgońskiemu łącznie 110 grzywien w ratach. W $1406 \mathrm{r}$. wypłacił więc sumę 15 grzywien, podobnie jak w kolejnych latach, by na koniec przekazać 20 grzywien. W latach 1406-1409 wpłacił razem sumę 60 grzywien ${ }^{43}$. Ta stosunkowo wysoka cena wiatraka zapewne oznaczała nabycie wraz z urządzeniem również dziedzicznego prawa do jego posiadania.

Oczywiście niższe koszty funkcjonowania wiatraków wiązały się również z ich mniejszą wydajnościa, a więc i potencjalnymi zyskami, jakie mogły wygenerować. W przypadku interesujących nas tu wiatraków działających na Żuławach pewne wzmianki na temat ich ekonomiki przynoszą źródła skarbowe i rachunkowe urzędników krzyżackich. Wskazują one na współudział finansowy Zakonu w organizacji produkcji, polegający na kredytowaniu kosztów nowych inwestycji ${ }^{44}$. W 1407 r. młynarz z wiatraka w Krzyżanowie był winny za wańczos do młyna. Zakon udzielał też pożyczek na zakup kamieni młyńskich młynarzowi w Mątowach ${ }^{45}$. Z 1412 r. pochodzi notatka, zawarta w księdze konwentu malborskiego, informująca o wypłacie wójtowi w Laskach z kasy konwentu aż 100 grzywien na zakup kamieni do wiatraków ${ }^{46}$. Za sumę tę można było nabyć wówczas kilka kompletów kamieni do wiatraków, co może wskazywać na fakt, że Zakon uczestniczył finansowo w utrzymaniu wiatraków prowadzonych przez młynarzy dzierżawców ${ }^{47}$.

${ }^{40}$ MK, s. 295. Na temat zasad zakupu kamieni młyńskich na terenie państwa krzyżackiego zob. R. Kubicki, dz. cyt., s. 155-163.

${ }^{41}$, „...] item die mole czu Soldaw czu buwen haben wir usgegeben 750 m”; Das grosse Ämterbuch des Deutschen Ordens, wyd. W. Ziesemer, Danzig 1921, s. 324.

${ }^{42}$ Geheimes Staatsarchiv Preußischer Kulturbesitz Berlin Dahlem (dalej: GStA PK), XX. HA, Ordensfoliant 83 (dalej: OF), Privilegien der Stadt Kulm, s. 96.

${ }^{43}$ „Niclus der wintmolner t. $110 \mathrm{~m}$. vor die wintmoel und sal do von beczalen $15 \mathrm{~m}$ in desem selbin iare uff Sente Iocops tag, dornach sal her alle ior gegeben $15 \mathrm{~m}$ uff den selben tag und czum leczten iare sal her gegeben $20 \mathrm{~m}$ bis das her beczalt; item dt. $15 \mathrm{~m}$ anno VI; (item dt. $15 \mathrm{~m}$ anno VII; item dt. $15 \mathrm{~m}$ anno VIII; item dt. $15 \mathrm{~m}$ anno IX)"; PKCh, s. 92.

${ }^{44}$ Dla komturstwa malborskiego przykłady zebrał W. Długokęcki, Z dziejów młynarstwa..., s. 56.

${ }^{45}$ HRD, s. 46.

${ }^{46}$ MK, s. 296; R. Kubicki, dz. cyt., s. 76.

${ }^{47} \mathrm{Za}$ taką interpretacją opowiedział się W. Długokęcki, $Z$ dziejów mtynarstwa..., s. 56; zob. też R. Kubicki, dz. cyt., s. 76. 


\section{Wiatraki na Żuławach w ekonomice krzyżackiej w pierwszej polowie XV w.}

Na znaczenie wiatraków dla gospodarki poszczególnych urzędów krzyżackich na Żuławach pośrednio wskazują sumaryczne zestawienia dochodów wójtostw i prokuratorii zakonnych uzyskiwanych z młynów od końca XIV do początków XV w. (zob. tab. 1).

Tabela 1. Czynsz z młynów w poszczególnych jednostkach administracyjnych komturstwa malborskiego ${ }^{48}$

\begin{tabular}{|c|c|c|c|}
\hline Lp. & $\begin{array}{l}\text { Jednostka } \\
\text { administracji }\end{array}$ & Lata & Dochód z młynów (wg czynszu planowanego) \\
\hline 1. & $\begin{array}{l}\text { wójtostwo } \\
\text { w Laskach }\end{array}$ & $\begin{array}{l}1404,1407 \\
1413 \\
1415 \\
1444\end{array}$ & $\begin{array}{l}2250 \text { korców żyta i } 90 \text { pszenicy, } 1150 \text { korców słodu } \\
1800 \text { korców maki, } 920 \text { korców słodu } \\
1800 \text { korców mąki, } 900 \text { korców słodu }{ }^{49} \\
1562 \text { korce maki żytniej, } 76 \text { korców mąki pszennej, } \\
810 \text { korców słodu }\end{array}$ \\
\hline 2. & $\begin{array}{l}\text { okręg rybicki } \\
\text { w Szkarpawie }\end{array}$ & $\begin{array}{ll}1387, & 1392, \\
1395, & 1404, \\
1409 & \\
1414 & \\
1419, & \\
1422 & \end{array}$ & $\begin{array}{l}585 \text { korców żyta } \\
52 \text { grzywny minus } 1 \text { wiardunek } \\
60 \text { grzywien i } 7 \text { wiardunków }\end{array}$ \\
\hline 3. & $\begin{array}{l}\text { prokuratoria } \\
\text { w Matowach }\end{array}$ & $\begin{array}{l}1381 \\
1387\end{array}$ & $\begin{array}{l}480 \text { korców ziarna, } 22 \text { korce pszenicy, } 28 \text { korców } \\
\text { słodu, } 600 \text { korców żyta, } 300 \text { korców jęczmienia, } 1500 \\
\text { korców owsa } \\
480 \text { korców żyta, } 22 \text { korce pszenicy, } 28 \text { korców słodu }\end{array}$ \\
\hline 4. & $\begin{array}{l}\text { prokuratoria } \\
\text { w Lasowicach }\end{array}$ & 1387 & $\begin{array}{l}281 \text { korców jęczmienia, } 200 \text { korców żyta, } 1225 \text { kor- } \\
\text { ców owsa, } 110 \text { korców pszenicy }\end{array}$ \\
\hline 5. & $\begin{array}{l}\text { wójtostwo } \\
\text { w Grabinach }\end{array}$ & $\begin{array}{l}1409 \\
1410 \\
1417\end{array}$ & $\begin{array}{l}990 \text { korców żyta, } 200 \text { korców słodu, } 16 \text { grzywien } \\
420 \text { korców żyta na strychu i } 450 \text { korców z wiatra- } \\
\text { ków }^{50} \\
525,5 \text { korców żyta, } 165 \text { korców słodu }\end{array}$ \\
\hline
\end{tabular}

Źródło: Das Marienburger Ämterbuch, wyd. W. Ziesemer, Danzig 1916, s. 28-32, 43-45, 47, 52, 54-55, $57-58,73-75,83,86$.

${ }^{48}$ System miar zbożowych w państwie krzyżackim wyglądał następująco: 1 łaszt $(3300 \mathrm{l})=60$ korców $(1$ korzec $=55 \mathrm{l})=960$ miarek $($ mac, 1 miarka, maca $=3,4 \mathrm{l})$; zob. W. Odyniec, dz. cyt., s. 404.

49 W drugim wykazie z 1415 r. było 1796 korców mąki i 930 korców słodu; Das Marienburger Ämterbuch, wyd. W. Ziesemer, Danzig 1916 (dalej: MA), s. 47.

${ }^{50}$ Wskazuje to, że poza młynem wodnym w dworze w Grabiach wszystkie pozostałe urządzenia były wiatrakami. Tezę tę wysunął w oparciu o przytoczony zapis W. Długokęcki, $Z$ dziejów mtynarstwa..., s. 25. 
Odnotowana w powyższej tabeli zmiana $\mathrm{w}$ formie pobierania czynszu w przypadku wójta w Laskach wskazuje, że pomiędzy 1408 a 1412 r. dokonano reformy. W miejsce ziarna zaczęto pobierać mąkę. Musiało się to zapewne wiązać z zawarciem nowych kontraktów z dzierżawcami. Prawdopodobnie miało to związek z koniecznością odbudowy gospodarczej Żuław, po zniszczeniach dokonanych przez zagony tatarskie i litewskie, które przybyły pod Malbork jako wsparcie dla wojsk króla Jagiełły. Pojawienie się ich na tych terenach wywołało powszechna panikę, a gdy Tatarzy przekroczyli Nogat, chłopi rozpoczęli masowe ucieczki. Tatarzy dotarli również nad Zalew Wiślany i przekroczyli Wisłę, tu jednak w obronie Żuław Steblewskich straż na rzece trzymali Gdańszczanie, którzy zadali agresorom znaczne straty. Najeźdźcy w służbie królewskiej dokonywali wielu grabieży i zniszczeń, tak że sam król musiał posłać swych ludzi do Grabin i Szkarpawy, aby oswobodzili miejscową ludność z ich rą ${ }^{51}$. Ze skutkami tych wypadków należy najpewniej łączyć fakt wielkich inwestycji, odbudowy po zniszczeniach wojennych, co poświadcza wspomniane już wypłacenie w 1412 r. wójtowi w Laskach 100 grzywien na zakup kamieni do wiatraków, a prokuratorowi w Mątowach 24 grzywny na budowę młyna w Starej Kościelnicy i zakup kamieni młyńskich ${ }^{52}$. Może to oznaczać, że wszystkie wiatraki w prokuratorii w Mątowach i wójtostwie w Laskach zostały w 1410 r. zniszczone przez Tatarów. Straty te obejmowały najpewniej i inne części Żuław. Podobnie jak w wójtostwie w Laskach, również w prokuratorii w Szkarpawie przed 1413 r. dokonano zamiany czynszu pobieranego dotychczas w zbożu na czynsz w pieniądzu. Zapewne objęto tą regulacją wszystkie istniejące tam wówczas wiatraki, aby nie różnicować pozycji ekonomicznej ich użytkowników. Nowy wymiar czynszu w obu jednostkach administracyjnych wskazuje na kompleksową reformę gospodarki młyńskiej na tym terenie. Zmierzała ona zapewne najpierw do odbudowy gospodarki młyńskiej, a potem także zwiększenia dochodów urzędników krzyżackich, choć jej efekty mogłyby okazać się przeciwne do planowanych. Dla przykładu rybicki (niem. Fischmeister) w Szkarpawie do 1409 r. pobierał czynsz w wysokości 585 korców żyta, co przy jego cenie z 1411 r. (54 fenigi za korzec) dawałoby zysk w wysokości około 43 grzywien i 3 wiardunków ${ }^{53}$.

${ }^{51} \mathrm{Na}$ temat tych wydarzeń zapiski kronikarskie zob. Johanns von Posilges, Officials von Pomesanien Chronik des Landes Preussen, wyd. E. Strehlke, w: Scriptores rerum Prussicarum, t. 3, Leipzig 1870, s. 320.

${ }^{52}$ MK, s. 295-296.

${ }^{53}$ Ceny żyta podano w oparciu o zestawienia L. Webera, Preussen vor 500 Jahren, culturhistorischer, statistischer und militarischer Beziehung nebst Special-Geographie, 
W cenach żyta z 1414 r. (69 fenigów za korzec) dałoby to dochód w wysokości około 56 grzywien i 2 wiardunki. Zanotowany w 1414 r. czynsz z młynów rybickiego, wynoszacy 52 grzywien bez 1 wiardunku, wskazuje, że cenę korca żyta przeliczono po 63,7 feniga, a więc po średnim kursie z kilku poprzednich lat. W późniejszym czasie cena żyta jednak wyraźnie wzrosła i w $1421 \mathrm{r}$. wynosiła 126 fenigów za korzec, co według dawnego wymiaru w zbożu dałoby rybickiemu zysk w wysokości ponad 103 grzywien. Tymczasem jego dochody z kontraktów młyńskich w 1422 r. wyniosły tylko 60 grzywien i 7 wiardunków. W następnych latach sytuacja wyglądała podobnie. W 1428 r. cena żyta doszła do 216 fenigów za korzec, by w latach 1431 i 1436 spaść do 72 fenigów. W innych latach zawsze przekraczała jednak pułap 100 fenigów. Okazało się, że zamiana czynszu zbożowego na pieniężny w tym okresie była niekorzystna dla urzędników zakonnych. Być może zdawano sobie z tego sprawę - wskazywałoby to na pewną przymusowość decyzji o reformie dokonanej na Szkarpawie lub też zawarcie nowych kontraktów, płatnych w pieniądzu, przenosiło na użytkowników młynów obowiązek samodzielnego zaopatrywania się w kamienie młyńskie, co równoważyłoby mniejsze zyski z kontraktów dla rybickiego. Niestety, źródło nie określa, jaką część urządzeń przemiałowych stanowiły w poszczególnych prokuratoriach wiatraki. Dopiero wykaz czynszowy pochodzacy sprzed 1413 r. przynosi pewne informacje na ten temat. Według tego zestawienia mistrz rybicki w Szkarpawie otrzymywał z 5 wiatraków czynsz roczny w wysokości 60 grzywien i 7 wiardunków, natomiast prokurator $\mathrm{w}$ Lasowicach $\mathrm{z}$ trzech wiatraków -600 korców żyta $^{54}$ (zob. tab. 2).

Z danych zawartych w powyższej tabeli wynika, że dochody wyłącznie $\mathrm{z}$ wiatraków pobierali prokurator w Lasowicach i rybicki w Szkarpawie. W tych jednostkach administracji zakonnej istniało wówczas łącznie osiem wiatraków. Z późniejszych wzmianek wiadomo, że czynsz prokuratorowi w Szkarpawie płaciły wiatraki w Leśnowie i Mikosze$w_{i}^{55}$, a w Lasowicach dwa wiatraki położone przed Lasowicami Wielkimi ${ }^{56}$. Ponadto do Szkarpawy najpewniej czynsz płaciły także dwa

\footnotetext{
Danzig 1878, s. 168. Autor ten zaczerpną je z cytowanej tu księgi czynszowej komtura domowego w Malborku (Das Zinsbuch des Hauses Marienburg). Notują one ceny zboża w komturstwie malborskim, a więc także z terenu Żuław, i zapewne odpowiadaja sumom płaconym chłopom żuławskim.

${ }^{54}$ Das grosse Zinsbuch des Deutschen Ritterordens 1414-1438, wyd. P.G. Thielen, Marburg 1958 (dalej: GZB), s. 12.

${ }^{55}$ GStA PK, XX. HA, OF 97, k. 92v (Leśnowo); OF 97, k. 50v (Mikoszewo).

${ }^{56}$ GStA PK, XX. HA, OF 97, k. 73v.
} 
Tabela 2. Czynsz z młynów w poszczególnych jednostkach administracyjnych komturstwa malborskiego sprzed $1413 \mathrm{r}$.

\begin{tabular}{|c|c|c|c|c|}
\hline Lp. & $\begin{array}{l}\text { Jednostka } \\
\text { administracji }\end{array}$ & Dochód z młynów & $\begin{array}{c}\text { Dochód } \\
\text { z wiatraków }\end{array}$ & Inne dochody \\
\hline 1. & $\begin{array}{l}\text { wójtostwo } \\
\text { w Laskach }\end{array}$ & $\begin{array}{l}1976 \text { korców żyta, } \\
\text { maki i pszenicy, } \\
950 \text { korców słodu }\end{array}$ & & 387 grzywien \\
\hline 2. & $\begin{array}{l}\text { okreeg rybicki } \\
\text { w Szkarpawie }\end{array}$ & & $\begin{array}{l}60 \text { grzywien } \\
\text { i } 7 \text { wiardunków }\end{array}$ & \\
\hline 3. & $\begin{array}{l}\text { prokuratoria } \\
\text { w Mątowach }\end{array}$ & $\begin{array}{l}420 \text { korców żyta, } \\
14 \text { korców pszenicy, } \\
38 \text { korców słodu }\end{array}$ & & 50 grzywien \\
\hline 4. & $\begin{array}{l}\text { wójtostwo } \\
\text { w Sztumie }\end{array}$ & 1150 korców mąki & & 44,5 grzywny \\
\hline 5. & $\begin{array}{l}\text { prokuratoria } \\
\text { w Lasowicach }\end{array}$ & & 600 korców żyta & \\
\hline 6. & $\begin{array}{l}\text { wójtostwo } \\
\text { w Grabinach }\end{array}$ & $\begin{array}{l}1350 \text { korców ziarna, } \\
255 \text { korców słodu }\end{array}$ & & $\begin{array}{l}152 \text { grzywny minus } \\
1 \text { wiardunek z kar- } \\
\text { czem i od zagrod- } \\
\text { ników }\end{array}$ \\
\hline
\end{tabular}

Źródło: Das grosse Zinsbuch des Deutschen Ritterordens 1414-1438, wyd. P.G. Thielen, Marburg 1958, s. $12-13$.

wiatraki w Żelichowie ${ }^{57}$. Z kolei w 1444 r. czynsz z młynów pobierany przez wójta w Laskach wynosił, według zawartych kontraktów, 1562 korców mąki żytniej, 76 korców mąki pszennej i 810 korców słodu. W okresie od 25 XII 1443 do 29 VI 1444 r. wpłynęło ogółem 57,5 korca mąki pszennej, 960 korców żytniej i 427 korców słodu ${ }^{58}$. Z przytoczonych zestawień sumarycznych, dochodów poszczególnych prokuratorii, wynika pośrednio model zarządzania młynami i wiatrakami. Zazwyczaj były one dzierżawione młynarzom za czynsz, wyrażony w pieniądzu lub odpowiedniej ilości zboża, który należało uiszczać corocznie. Płacili go oni z części dochodów młyna, które pochodziły z opłaty przemiałowej wnoszonej przez chłopów mielących zboż ${ }^{59}$. Nabycie prawa do gospoda-

${ }^{57}$ ZHM, s. 31.

${ }^{58}$ MA, s. 52.

${ }^{59}$ Zgodnie z ordynacją młyńską wydaną około lat 1335-1341, którą ogłosił wielki mistrz Zakonu Krzyżackiego Dytrych von Altenburg, od każdego zmielonego korca (mensura, Scheffel = korzec) należało wnieść opłatę, tzw. miarę (niem. mecze $=$ maca). Wynosiła ona $1 / 16$ korca $(1$ korzec $=$ ok. 55 l, to jest około 3,4 l). Ustalono także, że w przypadku przemiału przy pomocy czeladników młyńskich za zmielenie 2 korców zboża i ześrutowanie 6 korców słodu miano płacić dodatkowo 1 denar (fenig). Jednocześnie nie wolno było jednak zmuszać nikogo, kto chciał mielić samodzielnie, do korzystania z czeladników młyńskich; PrU, t. 3, wyd. M. Hein, Königsberg 1944, nr 416, s. 285. 
rowania młynem mogło opierać się także na przywileju młyńskim, dotyczącym nadania młyna z prawem jego dziedziczenia, jak było to najpewniej w przypadku młynarza w Dąbrówce ${ }^{60}$. Podobnie młynarz w Lipince płacił czynsz wieczysty od łana ziemi, w wysokości 4 grzywien ${ }^{61}$.

Uzyskane ze źródeł dane pozwalaja na pewne szacunki dotyczace możliwości przemiałowych wiatraków ${ }^{62}$. Jak pamiętamy, przed $1413 \mathrm{r}$. prokurator w Lasowicach z trzech wiatraków uzyskał 600 korców żyta ${ }^{63}$. Aby opłacić przeciętny czynsz w wysokości 200 korców rocznie z wiatraka trzeba było zmielić 3200 korców żyta (opłata za przemiał wynosiła 1/16 korca). Oczywiście wiatrak mielił więcej, tak aby jego dzierżawca mógł uzyskać zadowalający zysk, w przypadku młynów wodnych zazwyczaj wynoszacy 1/5-1/4 całkowitych przychodów rocznych ${ }^{64}$. Jeśli dochód dzierżawcy miałby wynosić $1 / 5$ pobranego zboża, to wiatrak w prokuratorii lasowickiej musiałby mielić rocznie 4000 korców żyta (około 66 i 2/3 łaszta = 219978 l). Przyjmując, że 1001 zboża to $80 \mathrm{~kg}^{65}$, wiatrak mieliłby rocznie $176 \mathrm{t}$ (1760 kwintali) ${ }^{66}$. Wydaje się,

\footnotetext{
${ }^{60}$ „Niclus molner dedit 1 m. ewiges czins”; MK, s. 130.

${ }^{61}$ ZHM, s. 32.

${ }^{62}$ Ogólne szacunki na temat przeciętnej zdolności przemiałowej wiatraków zob.
}

R. Kubicki, dz. cyt., s. 190-191.

${ }^{63}$ GZB, s. 12.

${ }^{64} \mathrm{Na}$ dużą skalę zjawiska dzierżawy młynów za 1/4 lub 1/5 całkowitych przychodów może wskazywać fakt, że gdy w 1419 r. rozpatrywano w państwie krzyżackim sprawę podatku od ludności na spłacenie zobowiązań wojennych młynarze mieli płacić od każdego koła taki podatek jak od łanu ziemi, natomiast ci trzymajacy młyny za 1/4 lub 1/5 mieli płacić piątą część. „Item die molner, iclicher von eynem rade gleich eyner huben, sunder welche molner die do sitczen uff das fumfte adir vierde, sullen geben ir fumfte teil erem herren czu hulfe"; Acten der Ständetage Preussens unter der Herrschaft des Deutschen Ordens, wyd. M. Toeppen, t. 1, Leipzig 1878, nr 277, s. 338.

${ }^{65}$ Obecnie szacuje się, że $1000 \mathrm{l}$ pszenicy waży średnio $0,72-0,88 \mathrm{t}$, żyta $0,66-0,80 \mathrm{t}$, jęczmienia $0,65-0,75$ t, a owsa $0,40-0,60$ t. Współczynnik 0,8 przyjęła M. Dembińska, Przetwórstwo zbożowe $w$ Polsce średniowiecznej..., s. 185. Odrębną kwestia jest wzajemny stosunek łaszta do korca i problem dokładności pomiarowej stosowanych wzorników. Na ten temat zob. uwagi W. Kuli, Problemy $i$ metody historii gospodarczej, Warszawa 1963, s. 602-605.

${ }^{66}$ Uzyskane wyniki dość znacznie odbiegają od obliczeń M. Dembińskiej, która szacowała średni przerób jednego młyna wodnego (zapewne średnio wyższy niż wiatraka) na 750 kwintali $(75$ t) w XIII-XIV w. i 875 kwintali $(87,5$ t) w XV w., przy założeniu pracy przez 125 dni w roku; zob. M. Dembińska, Przetwórstwo zbożowe $w$ Polsce średniowiecznej..., s. 191. Inaczej Z. Podwińska, która dla młynów wodnych w Małopolsce w XV w. szacowała ich wydajność na 2000-2500 kwintali i to przy pracy 100 dni rocznie; zob. Z. Podwińska, Rozmieszczenie wodnych mtynów zbożowych $w$ Małopolsce $w$ XV wieku, KHKM, t. 18, 1970, nr 3, s. 391. Nie wchodząc w szczegółowe rozważania, należy wspomnieć, że dla państwa krzyżackiego dysponujemy szczegółowymi rachunkami dochodów urzędów młyńskich, które potwierdzaja, że młyny 
że jednostkowy wymiar czynszu zbożowego z innych wiatraków również wynosił szacunkowo pomiędzy 100 a 200 korców rocznie. W 1410 r. zanotowano, że wójt w Grabinach uzyskał z wiatraków 7,5 łaszta (450 korców), jeśli było ich wówczas sześć, o czym poniżej, to średni czynsz wynosiłby 75 korców ${ }^{67}$. Na wysokość czynszu płaconego przez inne wiatraki wskazuje także ich zadłużenie odnotowywane w księdze konwentu malborskiego. Wynosiło ono: w 1401 r. w Widowie Żuławskim 200 korców, w Kończewicach w 1402 r. 600 korców, w Bronowie w 1404 r. 100 korców, a w 1405 r. 200 korców $^{68}$, w Kmiecinie w 1406 r. 200 korców, a w kolejnym roku już 300 korców ${ }^{69}$. Był to więc zapewne zaległy czynsz z jednego lub kilku lat.

Niestety, źródła nie opisuja szczegółowo sieci młynów wodnych i wiatraków w poszczególnych wójtostwach i prokuratoriach komturstwa malborskiego, a jedynie łączne zestawienia dochodów tych jednostek administracyjnych z młynów wodnych i wiatraków. Również inne istniejące przekazy dalekie są od kompletności. Świadczy o tym najlepiej fakt, że w pochodzącym z początków XV w. (sporządzonym zapewne po 1410 r.) wykazie szosu (podatku) dla Żuław Steblewskich odnotowano wiatraki w Steblewie, Cedrach Wielkich, Koźlinach, Kiezmarku, Wocławach i Leszkowach ${ }^{70}$. Za wyjątkiem wiatraków w Kiezmarku i Steblewie w przypadku pozostałych jest to jedyna wzmianka źródłowa ${ }^{71}$. Zakładając, że wraz z młynem wodnym w Grabinach Zameczku wskazane wiatraki stanowiły pełną sieć istniejących tam urządzeń przemia-

wodne pracowały przez cały rok, z krótką przerwą przed Bożym Narodzeniem i Wielkanoca. W ten sposób liczba dni pracy wzrastała do ponad 300. W tym kontekście wysokość przemiału wiatraków w prokuratorii lasowickiej można uzgodnić z innymi szacunkami, również zwiększając odpowiednio liczbę dni ich pracy.

${ }^{67}$ MA, s. 29.

${ }^{68}$ MK, s. 55, 94, 146, 163.

${ }^{69}$ MK, s. 179, 193. Przypadek Kmiecina jest szczególnie zastanawiajaccy, gdyż była to wieś należąca do terytorium miejskiego Elblaga i jako taka podlegała władzom miejskim, a nie urzędnikowi krzyżackiemu.

${ }^{70}$ GStA PK, XX. HA, Ordensbriefarchiv (dalej: OBA), nr 28107; W. Długokęcki, Mtynarstwo..., s. 11. Wprawdzie w przywołanym wykazie młynarze z Kiezmarka i Wocławów nie zostali, tak jak inni, wprost określeni jako młynarze wiatraków (wintmolner), biorąc jednak pod uwagę lokalne warunki wodne, można stwierdzić, że zapewne istniały tam także wiatraki.

${ }^{71}$ Informacje z tego wykazu podatkowego mogą potwierdzać, że występujące w księdze rachunkowej konwentu malborskiego osoby z określeniem „molner” były rzeczywiście młynarzami. Z terenu Żuław wymieniono je, oprócz Steblewa, także we wsiach: Palczewo, Kończewice, Widowo Żuławskie, Szawałd, Dąbrowa, Bronowo i Pręgowo Żuławskie. Przypuszczenie na temat istnienia tam wiatraków wysunął wcześniej W. Długokęcki, Z dziejów mtynarstwa..., s. 28; tenże, Mtynarstwo..., s. 15. 
łowych, możemy porównać ją z poziomem produkcji rolniczej w tamtejszych wsiach (zob. tab. 3$)^{72}$.

Tabela 3. Powierzchnia wsi i sieć młynów na Żuławach Steblewskich

\begin{tabular}{|c|c|c|c|c|}
\hline Lp. & Nazwa wsi & Lata & $\begin{array}{l}\text { Powierzchnia } \\
\text { wsi (w lanach) }\end{array}$ & $\begin{array}{c}\text { (Młyn wodny/wiatrak) - } \\
\text { uwagi }\end{array}$ \\
\hline 1. & Grabiny Zameczek & & folwark zakonny & $\begin{array}{l}\text { młyn wodny w folwarku zakon- } \\
\text { nym }\end{array}$ \\
\hline 2. & Błotnik & $1402-1409$ & 40 & w 1429 wsi obniżono czynsz \\
\hline 3. & Bogatka & 1547 & 48 & w 1429 wsi obniżono czynsz \\
\hline 4. & Bystra & $1402-1409$ & 30 & \\
\hline 5. & Cedry Małe & 1402-1409 & 40 & \\
\hline 6. & Cedry Wielkie & $1402-1409$ & 79 & wiatrak \\
\hline 7. & Długie Pole & $1402-1409$ & 29 & \\
\hline 8. & Freiwald & 1402-1409 & 55 & $\begin{array}{l}\text { później wieś połączona z Krzy- } \\
\text { wym Kołem }\end{array}$ \\
\hline 9. & Guettland & $1402-1409$ & 25 & \\
\hline 10. & Kiezmark & 1349 & 63 & wiatrak \\
\hline 11. & Koszwały & 1334 & 50 & \\
\hline 12. & Koźliny & $1402-1409$ & 32 & wiatrak \\
\hline 13. & Krzywe Koło & $1402-1409$ & 15 & \\
\hline 14. & Leszkowy & $1402-1409$ & 58 & wiatrak \\
\hline 15. & Miłocin & $1402-1409$ & 54 & \\
\hline 16. & Osice & $1402-1409$ & 45,5 & \\
\hline 17. & Ostrowite & $1402-1409$ & 30 & \\
\hline 18. & Steblewo & $1402-1409$ & 59 & wiatrak \\
\hline 19. & Suchy Dąb & 1350 & 40 & \\
\hline 20. & Trutnowy & $1402-1409$ & 41 & \\
\hline 21. & Trzcinisko & 1354 & 17 & \\
\hline 22. & Wiślina & $1402-1409$ & 34 & \\
\hline 23. & Wiślinka & $1402-1409$ & 34 & w 1441 wsi obniżono czynsz \\
\hline 24. & Wocławy & 1384 & 60 & wiatrak \\
\hline 25. & Wróblewo & & b.d. & \\
\hline \multicolumn{3}{|c|}{ Razem } & 978,5 łana & 1 młyn wodny i 6 wiatraków \\
\hline
\end{tabular}

Źródło: M. Grzegorz, Osady Pomorza Gdańskiego w latach 1309-1454, Warszawa-Łódź 1990, s. 116-119.

${ }^{72} \mathrm{~W}$ stosunku do prezentowanego zestawienia w pierwszej połowie XV w. dokonały się pewne zmiany. Wyludniła się wieś Trzcinisko, obniżono zaś czynsz ze wsi Błotnik, Bogatka, Wiślinka. Ostatnie dwie być może całkowicie się wyludniły; zob. W. Długokęcki, Osadnictwo na Żuławach Gdańskich..., s. 55. 
Na terenie wójtostwa w Grabinach młyny obsługiwały wsie o ogólnej powierzchni około 980 łanów (16 464 ha) $)^{73}$. Pamiętamy, że czynsz pobierany przez władze z młynów wynosił w 1404 r. 2250 korców żyta, 90 pszenicy i 1150 korców słodu. Zakładając, że opłata przemiałowa - „maca” - wynosiła 1/16 z każdego korca zmielonego zboża i słodu, w 6 wiatrakach i młynie wodnym zmielono wówczas 36000 korców żyta, 1140 korców pszenicy i 18400 korców słodu, co daje w sumie 55540 korców zboża, a więc 3054700 l. Przy założeniu, że pod produkcję rolną oddawano 1/3 powierzchni wsi (326,6 łanu), łącznie z 1 łanu (16,8 ha) do przemiału w młynach oddawano 9353 l zboża, to jest $7482,4 \mathrm{~kg}$, a więc $\mathrm{z}$ hektara $445,4 \mathrm{~kg}(4,45 \mathrm{kwintala})$, a $\mathrm{z}$ łanu $748 \mathrm{~kg}$ (74,8 kwintala), przyjmując, że $100 \mathrm{l}$ zboża to $80 \mathrm{~kg}$. Wyniki te należy zestawić jeszcze z szacunkami na temat wielkości produkcji zbożowej. Według wyliczeń Stefana Chmielewskiego produkcja pszenicy, żyta i jęczmienia z 1 łanu wynosiła przy plonie 4 ziaren 38 kwintali, a przy plonie 5 ziaren 47 kwintali. Odejmując 10-12 kwintali potrzebnych na zasiew, do przemiału pozostawałoby 28-35 kwintali z łana ${ }^{74}$. Dla terenu Żuław otrzymaliśmy wynik 74,8 kwintala mielonego z łanu. Szacunki te moga być zbliżone do stanu rzeczywistego, jeżeli weźmiemy pod uwagę, że wydajność rolnicza tych terenów była znacznie wyższa od przeciętnej, a miejscowy chłopi, określani jako die werderer, płacili według ordynacji podatkowej z $1433 \mathrm{r}$. sumę o sto procent wyższą od pozostałych w państwie krzyżackim ${ }^{75}$.

${ }^{73} \mathrm{Dla}$ porównania wzmiankowany poniżej wiatrak w Mikoszewie pracował w 1437 r. dla 3 wsi o łącznej powierzchni 140 łanów: Mikoszewa - 42 łany, Przemysław - 62 łany i Jantar - 36 łanów; dane na podstawie: M. Grzegorz, Osady Pomorza Gdańskiego w latach 1309-1454, Warszawa-Łódź 1990, s. 143.

${ }^{74}$ S. Chmielewski, Gospodarka rolna i hodowlana Polski w XIV i XV w. (Technika $i$ rozmiary produkcji), „Studia z Dziejów Gospodarstwa Wiejskiego” 5, 1962, z. 2, s. 115-117; Z. Podwińska, dz. cyt., s. 390. Niższe szacunki plonów, wynoszących 3 ziarna, dające 27 kwintali z hektara, przyjęła M. Dembińska, Próba obliczenia wysokości plonów w królewskich dobrach allodialnych w XIV wieku, „Studia z Dziejów Gospodarstwa Wiejskiego” 4, 1961, z. 1, s. 7-18. Z kolei dla okresu nowożytnego szacunki mówiące o średnim wskaźniku plonów żyta wynoszącym 3,2 ziarna dla ekonomii malborskiej przeprowadził L. Żytkowicz, Ze studiów nad wysokościq plonów w Polsce od XVI do XVIII wieku, KHKM, t. 14, 1966, nr 3, s. 468.

${ }^{75}$ Acten der Ständetage Preussens..., t. 1, nr 442, s. 587; W. Długokęcki, Społeczeństwo wiejskie, w: Państwo zakonu krzyżackiego $w$ Prusach. Wtadza $i$ społeczeństwo, red. M. Biskup, R. Czaja, Warszawa 2008, s. 485. Jednocześnie należy jednak podkreślić, że w przypadku gdyby pod produkcję zbożową przeznaczano więcej niż 1/3 ogólnej powierzchni wsi, odpowiednio mniejszy byłby też przemiał liczony z łana. Również współczynnik wagi zboża 0,8 , jaki tu przyjęto, mógł mieć w innych latach niższą wartość. 
Obok systemu dzierżawy wiatraków, w którym Zakon ponosił część nakładów i pobierał odpowiedni czynsz wyrażany w zbożu lub pienią$\mathrm{dzu}$, istniały także wiatraki nadawane dziedzicznie w oparciu o przywileje, podobnie jak działo się to w przypadku młynów wodnych. Dla terenu Żuław znamy cztery dokumenty, dotyczące łącznie sześciu tego typu urządzeń. Wystawiono je dla nowych użytkowników wiatraka w Mikoszewie, dwóch położonych przed miastem Nowy Staw, dwóch przed dworem w Lasowicach Wielkich i jednego wiatraka znajdujacego się w Leśnowie. W przywileju z 29 VIII 1437 r. wielki mistrz Paweł von Russdorf nadał wiatrak ${ }^{76}$ położony w Mikoszewie młynarzowi Gerke ${ }^{77}$. Miał on pracować dla rybickiego w Szkarpawie za roczny czynsz w wysokości 10 grzywien, choć wcześniej wynosił on 13 grzywien, płatnych w dwóch ratach na św. Jakuba i Boże Narodzenie ${ }^{78}$. Nadano mu 3 morgi ziemi koło wiatraka oraz prawo do darmowego pozyskiwania drewna do budowy i naprawy młyna z lasów rybickiego szkarpawskiego oraz drewno opałowe. Przy remontach drewno to miało być wykorzystywane do budowy wału do przenoszenia napędu, koła palecznego i prętów ${ }^{79}$. Młynarz sam musiał się natomiast zaopatrywać w kamienie młyńskie ${ }^{80}$. Co ciekawe, ustalono, że w tym młynie przemiału mieli dokonywać chłopi z trzech wsi: Mikoszewo, Przemysław i Jantar ${ }^{81}$. Jest to jedyny znany przykład zastosowania przymusu mlewnego na opisywanym terenie. Być może tym należy tłumaczyć fakt, że czynsz, który z pustego wiatraka w $1431 \mathrm{r}$. wynosił 5 grzywien, podniesiono później do 13 i obniżono do 10 grzywien ${ }^{82}$. Wiatrak ten nie działał jednak zbyt długo, gdyż już w 1443 r. odnotowano, że był opuszczony ${ }^{83}$.

${ }^{76} \mathrm{~W}$ dokumencie mowa o młynie (mole). Istniał tam jednak wiatrak wzmiankowany około 1400 r.; ZHM, s. 39. W 1431 r. wiatrak był pusty; GStA PK, OBA, nr 5893.

${ }^{77}$ GStA PK, OF 97, k. 50v, dokument częściowo nieczytelny. Treść zachowana w transumpcie z 27 II 1586 r.; APG, Akta miasta Gdańska, Dokumenty i listy, sygn. 300,D/79, nr 27, s. 2-6. Treść dokumentu w oparciu o ten transumpt omówił W. Długokęcki, $Z$ dziejów mtynarstwa..., s. 55.

${ }^{78}$ We wszystkich wcześniejszych wykazach mowa jednak o czynszu wynoszacym 5 grzywien (ok. 1400 r.); ZHM, s. 39. Podobnie było w latach 1401-1403; MK, s. 50, 79-80, 110, 112 .

79, „[...] czu widder bewungen ader besserungen der berurten mole an wellen, rutten, kamphalcz und sust an anderen bawholcze"; GStA PK, OF 97, k. 50v.

${ }^{80}$ „[...] sullen die steyne tzu der mole selbist schicken”; tamże.

${ }^{81}$ Powierzchnia tych 3 wsi wynosiła w 1400 r. łącznie 140 łanów; M. Grzegorz, dz. cyt., s. 143.

${ }^{82}$ GStA PK, OBA, nr 5893.

${ }^{83}$ GStA PK, OBA, nr 8388, druk: J. Sarnowsky, Das Treßleramt des Deutschen Ordens in Preußen in der Zeit Ulrichs von Eisenhofen (1441-1446). Einige Dokumente zu seiner Amtsführung, „Beiträge zur Geschichte Westpreußens” 10, 1987, s. 205-209. 
Z kolei w 1440 r. wielki mistrz Paweł von Russdorf zatwierdził transakcje sprzedaży przez prokuratora w Lasowicach dwóch wiatraków położonych przed tamtejszym folwarkiem zakonnym. Kupił je młynarz Jorge za niewielką sumę 5 grzywien, które miał spłacać przez następne 5 lat, po jednej grzywnie na św. Marcina. Ponadto miał on rocznie płacić czynsz dla folwarku w Lasowicach w wysokości 6 łasztów (360 korców) słodu, płatnych kwartalnie, w równych częściach. Do wiatraków przynależało 12 mórg ziemi. Młynarz otrzymał także prawo do pobierania darmowego drzewa opałowego w lasach koło folwarku w Kościeleczkach, na tych samych zasadach jak mieszkańcy i zagrodnicy z wsi Tragamin. Młynarz sam miał się natomiast zaopatrywać w kamienie młyńskie. Ze szczególnej łaski przyznano mu też drewno budowlane z Boru Sztumskiego lub Lasu Montowskiego ${ }^{84}$. Z kolei w dokumencie z 14 IV 1440 r., dotyczącym nadania dwóch innych wiatraków położonych przed miastem Nowy Staw, ustalono, że nowy właściciel miał otrzymać łan ziemi we wsi Trepnowy, wolny od służby, dziedzicznie na prawie chełmińskim. Ponadto przyznano mu prawo do darmowego drewna budowlanego i użytkowego, ale tylko na potrzeby wiatraków (frey buwholcz und schirholcz alleyne tzu den benampten czwen wintmolen). W zamian miał płacić czynsz w wysokości 3 łasztów (180 korców) mąki żytniej, 60 korców mąki pszennej, 500 korców słodu w terminie na św. Grzegorza papieża i jednej grzywny dla dworu w Laskach $\mathrm{w}$ terminie na św. Marcina ${ }^{85}$. W przywileju na wiatrak w Leśnowie z 7 X 1441 r. zapisano natomiast, że wielki mistrz Konrad von Erlichshausen nadał go Mikołajowi dziedzicznie na prawie chełmińskim. Nowy właściciel miał sam pozyskiwać kamienie młyńskie i wszystkie inne potrzebne elementy. Zakon gwarantował mu darmowe drewno budowlane i użytkowe. Młynarz musiał powiadomić Zakon i uzyskać

${ }^{84},[. .$.$] sol her auch unserm hoffe Lesewitz vorbenampt alle ior ierlihen sechs leste$ meelcz czinsen von alle quatempore $1 \frac{1}{2}$ lest van em in den selben hoff andwerten. Her sal ouch czu dorselben molen haben 12 morgen ackers, wo man em die wirt beweisn und frey holczunge im Warnwschen Walde czu seyne feuwer in gleicher weyse, als die gertner und inwoner des dorffes Trageheym haben, ummb den willen das her die vorbenammpte molen selbst und alleyne mit molesteynen sal besorgen dorczu wir em nichts pflichtig sullen seyn czu helfen, von sunderlicher gnade sal her ouch haben frey buweholcz us der Stumeschenheyde adir us dem Montauschen walde"; GStA PK, OF 97, k. 73v; R. Kubicki, dz. cyt., s. 106.

${ }^{85}$, „[...] davor sol her und seyne nachkomelingen drey leste rockenmeel, eyne last weisenmeel und vunff hundert scheffel malczes uff sente Gregorn des heiligen Baptes und eyne mrg gewonlicher preuwscher montcze unsir hofe Leszke alle ior ierlich uff sente Merten des heiligen bischoffs tag tzu tczinsen seyn vorpflichtig"; GStA PK, OF 97, k. 76r. 
jego zgodę w razie sprzedaży lub zamiany. Ustalono, że miał on płacić czynsz w wysokości 8 grzywien rocznie dla dworu w Szkarpawie, płatnych na Wielkanoc i Boże Narodzenie ${ }^{86}$.

We wszystkich czterech przytoczonych dokumentach dotyczących sprzedaży lub nadania wiatraków uprzednio należących do Zakonu występuje kilka wspólnych elementów. Zakon, nadając wiatraki, przenosił na ich właścicieli obowiązek zaopatrywania się w kamienie młyńskie i inne potrzebne narzędzia do jego pracy, gwarantując tylko darmowe drewno budowlane i opałowe. $\mathrm{W}$ dwóch przypadkach ustalono czynsz w naturaliach, a w dwóch dość wysoki w pieniądzu. Nowi właściciele mieli go uiszczać na rzecz urzędników zakonnych w Szkarpawie, Laskach i Lasowicach. Widoczna w tych działaniach zbieżność czasowa i zastosowanie podobnych regulacji wskazuja na realizację szerszego planu, być może obejmujacego większą liczbę wiatraków, wcześniej zarządzanych bezpośrednio przez Zakon lub też porzuconych przez dotychczasowych dzierżawców na skutek ogólnego kryzysu gospodarczego wsi na tych terenach ${ }^{87}$. Działania te podejmowano zapewne w celu reorganizacji gospodarki młyńskiej poszczególnych jednostek administracyjnych. Zmierzały one do wyzbycia się urządzeń przemiałowych na rzecz dziedzicznych właścicieli, którzy zobowiąani byli do płacenia ustalonego z góry czynszu. Zwalniało to Zakon z kłopotliwego utrzymywania urządzeń, gwarantując jednocześnie stałe dochody dla poszczególnych urzędników. Przypomnijmy, że przed 1414 r. prokurator w Lasowicach uzyskiwał z wiatraków 600 korców żyta, a w 1440 r. z 2 wiatraków - 360 korców słodu. Rybicki w Szkarpawie przed 1414 r. otrzymywał czynsz z młynów 60 grzywien i 7 wiardunków z 5 wiatraków, w 1437 r. gwarantował sobie z wiatraka w Mikoszewie 10 grzywien, a w 1440 r. z wiatraka w Leśnowie kolejne 8. Natomiast wójt

${ }^{86},[\ldots]$ molensteynen und allerley andere notdorft und zubehorungen haben und besorgen, und wir und unser orden mit sulcher bewungen umbekein syn und bleyben sullen. Dorczu wir em in unsern welden, wo em das gelegen wirt syn, frey bawholcz und legerholcz czu notdorff synes feuers geben und goennen. Und wenn der benumpten Niclos syne elichen erben oder rechten nachkomelingen semliche wyndmole vorkoufft adir vorwechseln welde, das sullen sie ane unsir wisse und willen keyne macht haben. Umb sulcher begnedigung willen sullen der egenanten Niclos syne elichen erben und rechten nachkomelingen uns und unserm orden und nemlichen unseren hoffen zcur Schaffawe 8 mrk gewonlicher preussischer moncze vyre uff pfingsten und vyre uff wynachten alle ior ierlich vnuorzygen pflichtig syn zcu czinsen"; GStA PK, OF 97, k. 92v. Treść dokumentu zachowała się też w transumpcie z 1586 r.; APG, Akta miasta Gdańska, Dokumenty i listy, sygn. 300,D/79, nr 27, s. 7-10.

${ }^{87} \mathrm{Na}$ temat kryzysu gospodarczego wsi w północnej części Żuław Wielkich po 1410 r. zob. W. Długokęcki, Osadnictwo pótnocnej części Żuław..., s. 124-125. 
w Laskach w 1413 r. uzyskał z młynów 1800 korców mąki, 920 korców słodu, a w 1440 r. z 2 wiatraków 1 grzywnę oraz 180 korców mąki żytniej, 60 korców makki pszennej i 500 korców słodu. W ten sposób urzędnicy utrzymywali swe dochody, nie zajmując się ani administracją ani dostarczaniem do młynów kamieni młyńskich, jak robili to wcześniej (np. wspomniany wójt w Laskach, kupując kamienie młyńskie w 1412 r.). Charakterystyczne, że utrzymano także samą formę czynszu: w okręgu rybickiego szkarpawskiego płatnego w pieniądzu, a w pozostałych - w zbożu, mące i słodzie. Wysokość płaconego czynszu wskazuje na pewne zróżnicowanie pomiędzy poszczególnymi wiatrakami położonymi na Żuławach. Najwyższe czynsze płacono z wiatraków pracujących dla folwarków zakonnych, jak w Leśnowie -8 grzywien czy nawet 10 grzywien w Mikoszewie. Ten drugi posiadał jednak przymus mlewny z trzech okolicznych wsi. Dla porównania wiatrak w Żelichowie płacił 4 grzywny, a w Drewnicy - od 4 do 5 grzywien, ale razem z wsią. Różnice między czynszem z poszczególnych młynów wynikały zapewne $\mathrm{z}$ wielkości prowadzonego przemiału i dochodowości poszczególnych urządzeń. Przed 1413 r. łączne dochody z 8 wiatraków, pracujących $\mathrm{w}$ prokuratoriach $\mathrm{w}$ Lasowicach i Szkarpawie, wyniosły 60 grzywien, 7 wiardunków i 600 korców żyta. Dochody z młynów w pozostałych prokuratoriach i wójtostwach komturstwa malborskiego (Laski, Grabiny, Mątowy i Sztum) obejmowały natomiast 3760 korców żyta i pszenicy, 1150 korców mąki oraz 1243 korce słodu. Niestety, nie wiadomo, jaką ich część przynosiły wiatraki, a jaką młyny wodne. Z przytoczonych danych wynika jednak wyraźnie, że wiatraki były podstawa młynarstwa w okręgu szkarpawskim oraz że odgrywały ważną rolę na Żuławach Steblewskich, gdzie jedyny młyn wodny Zakon posiadał w Grabinach Zameczku. Wydaje się, że miały one istotne znaczenie także w wójtostwie leskim oraz prokuratorii lasowickiej i mątowskiej. Pomocnicze funkcje spełniały natomiast w wójtostwie sztumskim.

Podsumowując niniejsze rozważania, można stwierdzić, że wiatraki w okresie średniowiecza, zapewne już w pierwszej połowie XIV w., stały się ważnym elementem gospodarki młyńskiej na Żuławach, pełniąc tę rolę przez kolejne stulecia ${ }^{88}$. Oczywiście w późniejszym czasie działały one nie tylko jako młyny zbożowe, związane z produkcją rolna, ale także wiatraki obsługujace system odwadniajacy tereny rolnicze narażone na zalewanie. Funkcje te pełniły jeszcze w początkach XX w., a proces

${ }^{88}$ W 1818 r. na Żuławach Wielkich było 30 wiatraków zbożowych, a w 1930 r. - 32. Natomiast na Żuławach Małych (Fiszewskich) odpowiednio 5 i 11; zob. B. Schmid, Erhaltung von Windmühlen..., s. 26. 
ich destrukcji i znikania z krajobrazu przyspieszyło przede wszystkim zniszczenie wałów dokonane pod koniec wojny przez uciekających Niemców, a potem głębokie przemiany, jakie dokonały się we wszystkich sferach organizacji życia społecznego na tych terenach po II wojnie światowej ${ }^{89}$. Ze względu na specyfikę lokalnych warunków terenowych budowano je zazwyczaj w tych samych miejscach, które wyznaczono już w średniowieczu, zmieniała się jedynie ich konstrukcja (nowościa w okresie nowożytnym był wiatrak holenderski). W późniejszym czasie szersze zastosowanie znalazły obok wiatraków przemiałowych również wiatraki odwadniające. Niestety, do dziś zachowały się tylko dwa wiatrak przemiałowe: w Drewnicy (koźlak) i Palczewie (holender). Pozostają one skromnym świadectwem bogactwa tutejszej kultury materialnej i organizacji gospodarki wiejskiej w minionych wiekach.

Tabela 4. Wykaz wiatraków wzmiankowanych na Żuławach w pierwszej połowie XV w. ${ }^{90}$

\begin{tabular}{|c|c|c|c|c|c|c|c|c|c|}
\hline Lp. & 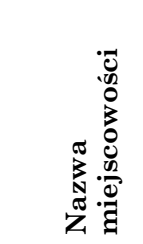 & 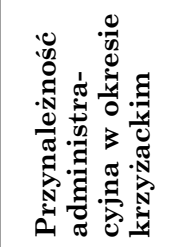 & 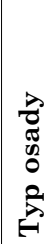 & 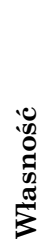 & 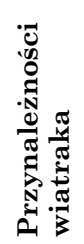 & 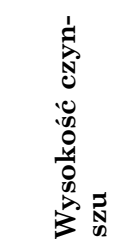 & 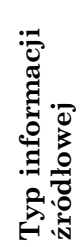 & 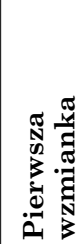 & Uwagi \\
\hline 1. & Boręty $^{91}$ & $\begin{array}{l}\text { malborskie, } \\
\text { wój. Laski }\end{array}$ & $\mathrm{w}$ & $\mathrm{zk}$ & & & wzm. & 1453 & wiatrak (?) \\
\hline 2. & Bronowo $^{92}$ & $\begin{array}{l}\text { malborskie, } \\
\text { prok. Szkar- } \\
\text { pawa }\end{array}$ & $\mathrm{w}$ & $\mathrm{zk}$ & & $\begin{array}{l}\text { dług } 100- \\
200 \text { kor- } \\
\text { ców }\end{array}$ & wzm. & 1404 & wiatrak (?) \\
\hline
\end{tabular}

${ }^{89}$ Rozmieszczenie wiatraków przemiałowych i odwadniających na przełomie XVIII i XIX w. prezentuje mapa L. von Schroettera, Karte von Ost-Preussen nebst Preussisch Litthauen und West-Preussen nebst dem Netzdistrict [...] 1796-1806, Sect. IX i X. Stan ich zachowania dla połowy lat pięćdziesiątych XX w. przedstawił J. Stankiewicz, Zabytki budownictwa i architektury na Żuławach, „Rocznik Gdański” 15/16, 1956/1957, s. 512, 526. Istniały wówczas jeszcze wiatraki w: Drewnicy, Kępniewie, Lichnowach, Lubiszewie, Marynowach, Mikoszewie, Nowym Stawie, Palczewie, Stogach (pow. Nowy Dwór), Wikrowie Małym i Żuławce.

${ }^{90}$ Dane zebrane w tabeli zostały już raz opublikowane, w innej formie, w ramach ogólnego wykazu młynów i wiatraków w państwie krzyżackim, w pracy: R. Kubicki, dz. cyt., s. 357-540. Ich ponowna prezentacja ma na celu łatwiejsze dotarcie do wszystkich informacji dotyczących wyłącznie wiatraków zlokalizowanych na Żuławach. W tabeli zastosowano następujace skróty: c - wykaz czynszowy lub podatkowy, f folwark, komor. - komornictwo, $\mathrm{m}$ - miasto, $\mathrm{p}$ - przywilej, prok. - prokuratoria, w wieś, wój. - wójtostwo, wzm. - wzmianka, zk - Zakon Krzyżacki.

${ }^{91} 5$ VI 1453 r. - wzmianka (GStA PK, Pergament Urkunden, Schublade XVII, nr 26).

${ }^{92} 1404$ r. - wzmianka (MK, s. 146); 1405 r. - wzmianka (MK, s. 163). 


\begin{tabular}{|c|c|c|c|c|c|c|c|c|c|}
\hline Lp. & 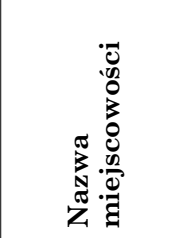 & 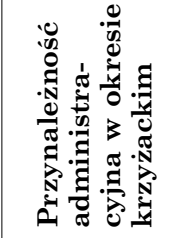 & 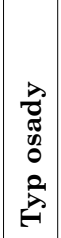 & 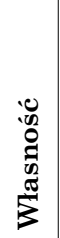 & 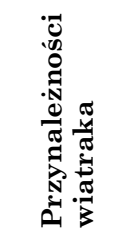 & 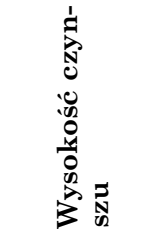 & 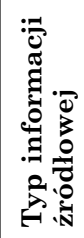 & 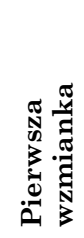 & Uwagi \\
\hline 3. & $\begin{array}{l}\text { Cedry Wiel- } \\
\text { kie }^{93}\end{array}$ & $\begin{array}{l}\text { malborskie, } \\
\text { wój. Gra- } \\
\text { biny }\end{array}$ & $\mathrm{w}$ & $\mathrm{zk}$ & & & $\mathrm{c}$ & $\begin{array}{l}\text { po } \\
1410\end{array}$ & \\
\hline 4. & Dąbrowa $^{94}$ & $\begin{array}{l}\text { malborskie, } \\
\text { wój. Laski }\end{array}$ & $\mathrm{w}$ & $\mathrm{zk}$ & & $\begin{array}{l}1 \text { grzywna, } \\
\text { czynsz } \\
\text { wieczysty }\end{array}$ & wzm. & 1404 & wiatrak (?) \\
\hline 5. & Drewnica $^{95}$ & $\begin{array}{l}\text { malborskie, } \\
\text { wój. Gra- } \\
\text { biny }\end{array}$ & $\mathrm{w}$ & $\mathrm{zk}$ & & $\begin{array}{l}3-5 \text { grzy- } \\
\text { wien }\end{array}$ & $\mathrm{c}$ & 1400 & \\
\hline 6. & Fiszewo $^{96}$ & $\begin{array}{l}\text { elblaskie, } \\
\text { komor. } \\
\text { fiszewskie }\end{array}$ & $\mathrm{w}$ & $\mathrm{zk}$ & $\begin{array}{l}1 \text { morga } \\
\text { ziemi } \\
\text { czynsz } 1 \\
\text { wiardu- } \text { nek }^{97}\end{array}$ & 4 grzywny & $\mathrm{c}$ & $\begin{array}{l}1402, \\
1451\end{array}$ & \\
\hline 7. & Kiezmark $^{98}$ & $\begin{array}{l}\text { malborskie, } \\
\text { wój. Gra- } \\
\text { biny }\end{array}$ & $\mathrm{w}$ & $\mathrm{zk}$ & & & $\mathrm{c}$ & 1427 & wiatrak (?) \\
\hline 8. & Kmiecin $^{99}$ & $\begin{array}{l}\text { elbląskie, } \\
\text { komor. } \\
\text { Pomen }\end{array}$ & $\mathrm{w}$ & $\mathrm{zk}$ & & $\begin{array}{l}\text { dług } 200- \\
300 \text { kor- } \\
\text { ców }\end{array}$ & wzm. & 1406 & $\begin{array}{l}\text { wiatrak (?), } \\
\text { wieś mia- } \\
\text { sta Elblaga }\end{array}$ \\
\hline
\end{tabular}

${ }^{93}$ XV w. - wzmianka (GStA PK, OBA, nr 28107).

${ }^{94} 1404$ r. - wzmianka (MK, s. 130).

${ }^{95}$ Przywilej ok. 1400 r. - wzmianka o czynszu (ZHM, s. 39); 29 IX 1400 r. wzmianka o czynszu (MK, s. 22); 1401 r. - wzmianka o czynszu (MK, s. 45, 50); 1402 r. - wzmianka o czynszu (MK, s. 74, 79); 1403 r. - wzmianka o czynszu (MK, s. 110, 111); 1404 r. - wzmianka o czynszu (MK, s. 130, 137); 1412 r. - wzmianka o czynszu (MK, s. 274), 1443 r. - wzmianka o pustym wiatraku (GStA PK, OBA, nr 8388).

${ }^{96}$ Przywilej 1402 r. - wzmianka o czynszu (APG, sygn. 369,1/2102, k. 26v); 29 IX 1426 r. - wzmianka o czynszu (GStA PK, OF 166n, s. 131); 1445 r. - wzmianka o czynszu (APG, sygn. 369,1/2103 k. 1r); 1 V 1446 r. - wzmianka o czynszu (GStA PK, OF 200b, t. 2, k. 146r); 13 IX 1446 r. - wzmianka o czynszu (Visitationen, t. 1, nr 120, s. 237); 1 V 1447 r. - wzmianka o czynszu (GStA PK, OF 200b, t. 2, k. 353v); 1 V 1449 r. - wzmianka o czynszu (GStA PK, OF 200b, t. 2, k. 226v, 229r-v, 241v, 271v); połowa XV w. - wzmianka o czynszu (APG, sygn. 369,1/2104a, s. 1); 1 V 1450 r. wzmianka o czynszu (GStA PK, OF 200b, t. 2, k. 21r); 25 XI 1451 r. - wzmianka o czynszu (Visitationen im Deutschen Orden im Mittelalter, wyd. M. Biskup, I. Janosz-Biskupowa, Marburg 2002 (Quellen und Studien zur Geschichte des Deutschen Ordens, 50), cz. 2: 1450-1519, t. 2, nr 176, s. 139).

${ }^{97}$ A. Semrau, Die Siedlungen im Kammeramt..., s. 59.

${ }_{98} 17$ IX 1427 r. - wzmianka o czynszu (MA, s. 36); XV w. - wzmianka o czynszu (GStA PK, OBA, nr 28107).

${ }^{99} 1406$ r. - wzmianka o młynarzu (MK, s. 179); 1407 r. - wzmianka (MK, s. 193). 


\begin{tabular}{|c|c|c|c|c|c|c|c|c|c|}
\hline 9. & $\begin{array}{l}\text { Kończe- } \\
\text { wice } 100\end{array}$ & $\begin{array}{l}\text { malbor- } \\
\text { skie, prok. } \\
\text { Mątowy? }\end{array}$ & $\mathrm{w}$ & $\mathrm{zk}$ & & $\begin{array}{l}\text { dług } 600 \\
\text { korców }\end{array}$ & wzm. & 1402 & wiatrak (?) \\
\hline 10. & Koźliny ${ }^{101}$ & $\begin{array}{l}\text { malborskie, } \\
\text { wój. Gra- } \\
\text { biny }\end{array}$ & $\mathrm{w}$ & $\mathrm{zk}$ & & & wzm. & $\begin{array}{l}\text { po } \\
1410\end{array}$ & \\
\hline 11. & $\begin{array}{l}\text { Krzyża- } \\
\text { nowo }\end{array}$ & $\begin{array}{l}\text { dzierzgoń- } \\
\text { skie, komor. } \\
\text { fiszewskie }\end{array}$ & $\mathrm{w}$ & $\mathrm{zk}$ & & & wzm. & 1407 & \\
\hline 12. & $\begin{array}{l}\text { Lasowice } \\
\text { Wielkie }^{103}\end{array}$ & $\begin{array}{l}\text { malborskie, } \\
\text { prok. laso- } \\
\text { wickie }\end{array}$ & $\mathrm{w}$ & $\mathrm{zk}$ & $\begin{array}{l}12 \text { mórg } \\
\text { ziemi }\end{array}$ & $\begin{array}{l}6 \text { łasztów } \\
\text { słodu }\end{array}$ & $\begin{array}{l}\text { wzm. } \\
\text { p }\end{array}$ & $\begin{array}{l}1407 \\
1440\end{array}$ & $\begin{array}{l}2 \text { wiatraki } \\
\text { czynsz dla } \\
\text { prokura- } \\
\text { tora w La- } \\
\text { sowicach }\end{array}$ \\
\hline 13. & Leklowy $^{104}$ & $\begin{array}{l}\text { dzierzgoń- } \\
\text { skie, komor. } \\
\text { fiszewskie }\end{array}$ & $\mathrm{w}$ & $\mathrm{zk}$ & $\begin{array}{l}1 / 2 \text { lana } \\
\text { ziemi } \\
(?)\end{array}$ & $\begin{array}{l}4 \text { łaszty } \\
\text { ziarna } \\
\text { i } 10 \text { kor- } \\
\text { ców słodu }\end{array}$ & wzm. & 1391 & $\begin{array}{l}\text { wiatrak } \\
\text { i młyn } \\
\text { wodny }\end{array}$ \\
\hline 14. & Leszkowy ${ }^{105}$ & $\begin{array}{l}\text { malborskie, } \\
\text { wój. Gra- } \\
\text { biny }\end{array}$ & $\mathrm{w}$ & $\mathrm{zk}$ & & & c & $\begin{array}{l}\text { po } \\
1410\end{array}$ & \\
\hline 15. & Leśnowo $^{106}$ & $\begin{array}{l}\text { malborskie, } \\
\text { wój. Laski }\end{array}$ & $\mathrm{w}$ & $\mathrm{zk}$ & & 8 grzywien & $\mathrm{p}$ & 1441 & $\begin{array}{l}\text { wiatrak, } \\
\text { czynsz dla } \\
\text { dworu krzy- } \\
\text { żackiego w } \\
\text { Szkarpawie }\end{array}$ \\
\hline 16. & Lipinka $^{107}$ & $\begin{array}{l}\text { malborskie, } \\
\text { wój. Laski? }\end{array}$ & $\mathrm{w}$ & $\mathrm{zk}$ & $\begin{array}{l}\text { łan } \\
\text { ziemi }^{108}\end{array}$ & $\begin{array}{l}300 \text { kor- } \\
\text { ców ziarna } \\
(1407 \text { r. })\end{array}$ & wzm. & 1396 & wiatrak \\
\hline 17. & Mątowy ${ }^{109}$ & $\begin{array}{l}\text { malborskie, } \\
\text { prok. w Mą- } \\
\text { towach }\end{array}$ & $\mathrm{f}$ & $\mathrm{zk}$ & & & wzm. & 1404 & $\begin{array}{l}\text { wiatrak } \\
\text { przed dwo- } \\
\text { rem }\end{array}$ \\
\hline
\end{tabular}

1001402 r. - wzmianka o młynarzu (MK, s. 94).

${ }^{101}$ XV w. - wzmianka (GStA PK, OBA, nr 28107).

${ }^{102} 1407$ r. - wzmianka (PKCh, s. 91); 1409 r. - wzmianka (PKCh, s. 91).

${ }^{103} 1407$ r. - wzmianka (MA, s. 86); poczatek XV w. - wzmianka o czynszu z trzech wiatraków (GZB, s. 13); przywilej 1440 r. - wzmianka o 2 wiatrakach (GStA PK, OF 97, k. 73v).

${ }^{104} 1391$ r. - wzmianka o młynarzu (ZHM, s. 51-52); ok. 1400 r. - wzmianka o czynszu (ZHM, s. 51-52); 1405 r. - wzmianka (PKCh, s. 92); 1406 r. - wzmianka o młynarzu (PKCh, s. 92); 1407 r. - wzmianka o młynarzu (PKCh, s. 92), 1410 r. - wzmianka o młynarzu (PKCh, s. 92).

${ }^{105}$ XV w. wzm. (GStA PK, OBA, nr 28107).

1067 X 1441 r. - przywilej na wiatrak (GStA PK, OF 97, k. 92v).

${ }^{107} 1396$ r. - wzmianka o wydatkach na budowę wiatraka (A. Sielmann, dz. cyt., s. 70); ok. 1400 r. - wzmianka (ZHM, s. 32; MK, s. 18); 1407 r. - wzmianka o młynarzu (MA, s. 86).

${ }^{108}$ Czynsz wieczysty w wysokości 4 grzywien (ZHM, s. 32).

1091404 r. - wzmianka (HRD, s. 46); 1417 r. - wzmianka (HRD, s. 93); XV w. wzmianka o czynszu (GZB, s. 12). 


\begin{tabular}{|c|c|c|c|c|c|c|c|c|c|}
\hline Lp. & 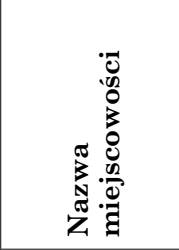 & 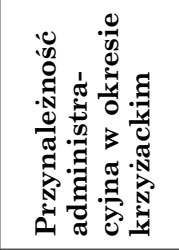 & 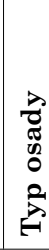 & 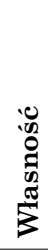 & 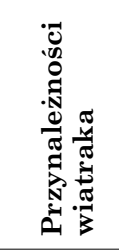 & 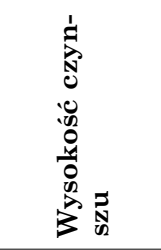 & 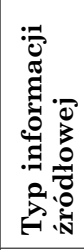 & 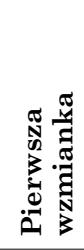 & Uwagi \\
\hline 18. & $\begin{array}{l}\text { Miko- } \\
\text { szewo }^{110}\end{array}$ & $\begin{array}{l}\text { malborskie, } \\
\text { wój. Gra- } \\
\text { biny }\end{array}$ & $\mathrm{w}$ & $\mathrm{zk}$ & & $\begin{array}{l}5 \text { grzywien } \\
\text { i } 6 \text { kur, } 10 \\
\text { grzywien }\end{array}$ & $\begin{array}{l}c \\
p\end{array}$ & $\begin{array}{l}1400 \\
1437\end{array}$ & $\begin{array}{l}\text { czynsz dla } \\
\text { rybickiego } \\
\text { w Szkar- } \\
\text { pawie, } \\
\text { także młyn } \\
\text { łodziowy }\end{array}$ \\
\hline 19. & $\begin{array}{l}\text { Nowa } \\
\text { Kościel- } \\
\text { nica }^{111}\end{array}$ & $\begin{array}{l}\text { malborskie, } \\
\text { prok. Szkar- } \\
\text { pawa }\end{array}$ & W & $\mathrm{zk}$ & $\begin{array}{l}\text { łan } \\
\text { ziemi }\end{array}$ & & wzm. & 1417 & wiatrak (?) \\
\hline 20. & $\begin{array}{l}\text { Nowy } \\
\text { Staw }\end{array}$ & $\begin{array}{l}\text { malborskie, } \\
\text { wój. Laski } \\
\text { (?) }\end{array}$ & $\mathrm{m}$ & $\mathrm{zk}$ & $\begin{array}{l}\text { łan } \\
\text { ziemi } \\
\text { w Tręp- } \\
\text { nowach }\end{array}$ & $\begin{array}{l}1 \text { grzywna } \\
+3 \text { łaszty } \\
\text { maki żyt- } \\
\text { niej, } 1 \\
\text { łaszt maki } \\
\text { pszennej, } \\
500 \text { kor- } \\
\text { ców słodu }\end{array}$ & $\begin{array}{l}\text { wzm. } \\
\mathrm{p}\end{array}$ & $\begin{array}{l}1402 \\
1440\end{array}$ & $\begin{array}{l}2 \text { wiatraki, } \\
1 \text { grzywna } \\
\text { dla dworu } \\
\text { krzyżac- } \\
\text { kiego } \\
\text { w Laskach }\end{array}$ \\
\hline 21. & Palczewo ${ }^{113}$ & $\begin{array}{l}\text { malborskie, } \\
\text { wój. Laski }\end{array}$ & $\mathrm{w}$ & $\mathrm{zk}$ & & & wzm. & 1399 & wiatrak (?) \\
\hline 22 . & $\begin{array}{l}\text { Pręgowo } \\
\text { Żuławskie }{ }^{114}\end{array}$ & $\begin{array}{l}\text { malborskie, } \\
\text { wój. Laski }\end{array}$ & $\mathrm{w}$ & $\mathrm{zk}$ & & $\begin{array}{l}2 \text { grzywny } \\
\text { i } 14 \text { szylin- } \\
\text { gów }\end{array}$ & wzm. & 1408 & wiatrak (?) \\
\hline 23. & $\begin{array}{l}\text { Stara } \\
\text { Kościel- } \\
\text { nica }^{115}\end{array}$ & $\begin{array}{l}\text { malborskie, } \\
\text { prok. w Mą- } \\
\text { towach }\end{array}$ & $\mathrm{w}$ & $\mathrm{zk}$ & & & wzm. & 1396 & wiatrak (?) \\
\hline
\end{tabular}

${ }^{110} \mathrm{~W} 1402 \mathrm{r}$. czynsz 5 grzywien, w $1431 \mathrm{r}$. czynsz 5 grzywien, wiatrak pusty. W dokumencie z $1437 \mathrm{r}$. mowa o obniżeniu czynszu z 13 do 10 grzywien, w $1443 \mathrm{r}$. wiatrak ponownie pusty. Około 1400 r. - wzmianka o czynszu (ZHM, s. 39); 1401 r. wzmianka o czynszu (MK, s. 50); 1402 r. - wzmianka o czynszu (MK, s. 79-80); 1403 r. - wzmianka o czynszu (MK, s. 110, 112); 1431 r. - wzmianka o czynszu i pustym wiatraku (GStA PK, OBA, nr 5893); 29 VIII 1437 r. - przywilej (GStA PK, OF 97, k. 50v; transumpt z 1586 r. - APG, sygn. 300,D/79, nr 27); XV w. - wzmianka o młynie pływającym i młynie olejarni (KKG, nr 226, s. 201); 1443 r. - wzmianka o pustym wiatraku (GStA PK, OBA, nr 8388).

${ }_{111} 1320$ r. - wzmianka o rezerwacji (CDW, t. 1, nr 204, s. 353); przed 1417 r. wzmianka o dawnym młynie krzyżackim (APG, sygn. 358, nr 116).

1121402 r. - wzmianka o młynarzu (MK, s. 80); 1409 r. - wzmianka (MK, s. 232-233); 14 IV 1440 r. - przywilej na dwa wiatraki koło miasta (GStA PK, OF 97, k. 76r).

${ }^{113} 1399$ r. - wzmianka o młynarzu (MK, s. 4).

1141408 r. - wzmianka o młynarzu (MK, s. 212); 1472 r. - wzmianka (W. Długokęcki, Mtynarstwo..., s. 15).

11525 V 1323 r. - wzmianka o rezerwacji Zakonu (PrU, t. 2, nr 407, s. 296); 1 V 1396 r. - wzmianka (MA, s. 74); 29 III 1412 r. - wzmianka o budowie młyna (MK, s. 295). 


\begin{tabular}{|c|c|c|c|c|c|c|c|c|}
\hline 24. & $\begin{array}{l}\text { Stara } \\
\text { Wisła }^{116}\end{array}$ & $\begin{array}{l}\text { malborskie, } \\
\text { prok. Laso- } \\
\text { wice (?) }\end{array}$ & $\mathrm{w}$ & $\mathrm{zk}$ & & wzm. & 1450 & \\
\hline 25. & Steblewo $^{117}$ & $\begin{array}{l}\text { malborskie, } \\
\text { wój. Gra- } \\
\text { biny }\end{array}$ & $\mathrm{w}$ & $\mathrm{zk}$ & 2 grzywny & $\mathrm{c}$ & 1400 & \\
\hline 26. & Szawałd $^{118}$ & $\begin{array}{l}\text { malborskie, } \\
\text { prok. Laso- } \\
\text { wice }\end{array}$ & $\mathrm{w}$ & $\mathrm{zk}$ & $\begin{array}{l}9 \text { wiardun- } \\
\text { ków }\end{array}$ & wzm. & 1401 & wiatrak (?) \\
\hline 27. & Tuja $^{119}$ & $\begin{array}{l}\text { malborskie, } \\
\text { wój. Laski }\end{array}$ & $\mathrm{w}$ & $\mathrm{zk}$ & & wzm. & 1404 & \\
\hline 28. & $\begin{array}{l}\text { Widowo } \\
\text { Żuławskie }{ }^{120}\end{array}$ & $\begin{array}{l}\text { malborskie, } \\
\text { prok. Laso- } \\
\text { wice }\end{array}$ & $\mathrm{w}$ & $\mathrm{zk}$ & $\begin{array}{l}\text { dług } 200 \\
\text { korców }\end{array}$ & wzm. & 1401 & wiatrak (?) \\
\hline 29. & Wocławy $^{121}$ & $\begin{array}{l}\text { malborskie, } \\
\text { wój. Gra- } \\
\text { biny }\end{array}$ & $\mathrm{w}$ & $\mathrm{zk}$ & & $\mathrm{c}$ & $\begin{array}{l}\text { po } \\
1410\end{array}$ & \\
\hline 30. & $\dot{Z}_{\text {elichowo }}{ }^{122}$ & $\begin{array}{l}\text { malborskie, } \\
\text { wój. Laski } \\
\text { (?), elblaski, } \\
\text { komor. } \\
\text { Pomen (?) }\end{array}$ & $\mathrm{w}$ & $\mathrm{zk}$ & 4 grzywny & $\mathrm{c}$ & 1400 & 2 wiatraki \\
\hline
\end{tabular}

${ }^{116} 1450$ r. - wzmianka o młynarzu z wiatraka (Regesta Historico-Diplomatica Ordinis S. Mariae Theutonicorum, cz. 1, t. 1, oprac. E. Joachim, wyd. W. Hubatsch, Göttingen 1948, nr 10514); 4 VI 1453 r. - wzmianka (GStA PK, OBA, nr 12084); 9 VI 1453 r. - wzmianka o młynie (GStA PK, Pergament Urkunden, Schublade XVII, nr 29).

1171400 r. - wzmianka o młynarzu (MK, s. 23); XV w. - wzmianka (GStA PK, OBA, nr 28107).

1181401 r. - wzmianka o młynarzu (MK, s. 77).

1191404 r. - wzmianka (HRD, s. 46).

${ }^{120} 1401$ r. - wzmianka o młynarzu (MK, s. 55).

${ }^{121}$ XV w. - wzmianka (GStA PK, OBA, nr 28107).

${ }^{122}$ Około $1400 \mathrm{r}$. istniały tam dwa wiatraki, każdy płacił czynsz po 2 grzywny $\mathrm{w}$ dwóch terminach. Jeden z wiatraków był wówczas opuszczony. $21 \mathrm{~V} 1328 \mathrm{r}$. wzmianka o rezerwacji Zakonu (PrU, t. 2, nr 616, s. 407); ok. 1400 r. - wzmianka o czynszu z 2 wiatraków (ZHM, s. 31); 1400 r. - wzmianka o czynszu (MK, s. 19); 1401 r. - wzmianka o czynszu (MK, s. 39); 26 III 1402 r. - wzmianka o czynszu (MK, s. 75); 1403 r. - wzmianka o czynszu (MK, s. 105, 111); 1404 r. - wzmianka (HRD, s. 46); 1407 r. - wzmianka o czynszu z wiatraka (MK, s. 196); 1408 r. - wzmianka o czynszu (MK, s. 209); 1417 r. - wzmianka (HRD, s. 94); 1443 r. - wzmianka o pustym wiatraku (GStA PK, OBA, nr 8388, druk: J. Sarnowsky, dz. cyt.). 
Rafał Kubicki

\author{
Windmills in the Żuławy Region during the First Half \\ of the Fifteenth Century
}

(Summary)

Studies on the living conditions of the rural population and the organisation of agriculture in the Middle Ages have a long tradition. Some of the issues examined include mills in the State of the Teutonic Order. Other publications consider the specific nature of the Żuławy region under the Teutonic Order and the Polish-Lithuanian Commonwealth. This article focuses on reconstructing the significance of windmills for the mill economy in this area. The mills within the Teutonic State were supervised by a number of administrative units. The northern part of Gdańsk Żuławy (known in the Middle Ages as Stüblau (in Pol. Steblewskie or Żuławy Małe) was administered by the forestry office of the Danzig (Gdańsk) commandry, the strip of land between the Vistula and the River Mottlau (Motława) was governed by a Vogt whose seat was in Herrengrebin (Grabiny Zameczek) itself under the commandry of Marienburg (Malbork), while the southern part was supervised by the Vogt of Dirschau (Tczew). Gross Werder (Great Żuławy) was administered by the commandry of Marienburg, and Fischauer Werder (Fiszewskie Zuławy) - by the Komtur (commander) of Elbing (Elblag) and Christburg (Dzierzgoń). The different principles of administering these regions resulted predominantly from the local water conditions and the need for the farmland's constant drainage. One of the elements of the region's specificity was the organisation of flourmilling, which owing to geographical conditions could not be based on a network of water mills, as was the case elsewhere. Water mills were therefore replaced by windmills, which became a prominent element of Żuławy's milling industry in the Middle Ages, perhaps even in the first half of the fourteenth century, and continued to play this role in successive centuries.

The data quoted clearly show that windmills were the foundation of the milling industry in the Scharpau (now: Szkarpawa) region and played a significant role in Stüblau, where the Order owned one water mill in Herrengrebin. It would seem that they were also of fundamental significance in the Vogtei of Leske (Laski) and the area under the Pfleger of Lassowitz (Lasowice) and Montau (Mątowy). In the territory under the Vogt of Stuhm (Sztum) the mills fulfilled auxiliary functions. The mills in question subsequently functioned not only as flour mills, associated with farm production, but also helped drain farmland threatened by flooding. They continued to fulfil this role until the early 1900s, and their subsequent destruction and ensuing absence in the landscape were accelerated by the destruction of mounds by the fleeing Germans at the end of the war, as well as the profound transformations which affected all domains of social life in this area following World War II. Owing to the specific local conditions, mills were usually erected on the same sites as they had been in the Middle Ages; only the method of their construction 
changed (early modern novelties included the Dutch mills). In subsequent years, mills for land drainage were used on a larger scale alongside grist mills. Unfortunately, only two such mills have survived: a post mill in Schönbaum (Drewnica) and a Dutch mill in Palschau (Palczewo), which are testimony of the great diversity of the local material culture and organisation of the rural economy in past centuries.

Rafał Kubicki - Instytut Historii Uniwersytetu Gdańskiego; e-mail: hisrk@univ.gda.pl 


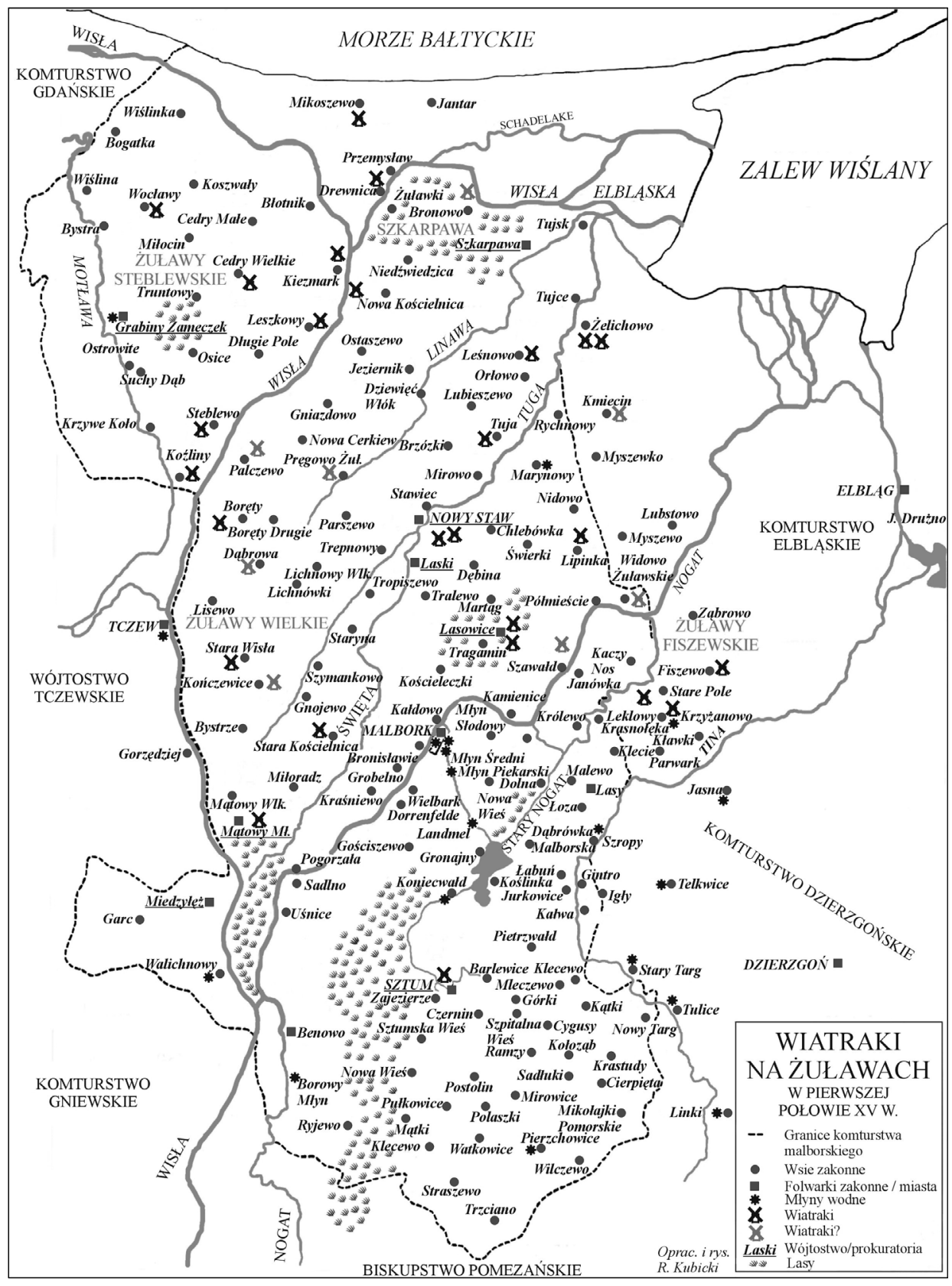

